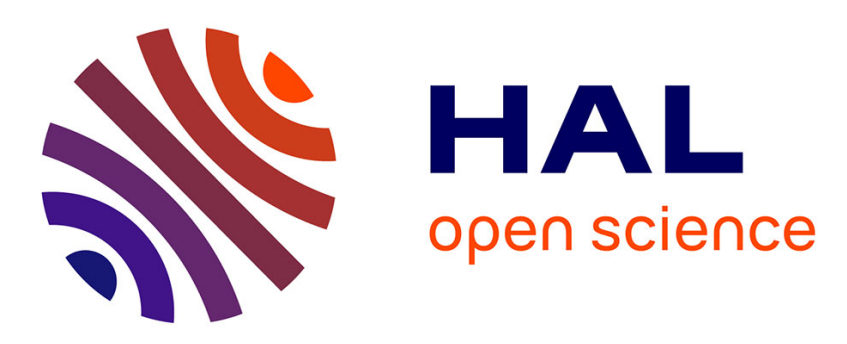

\title{
Polyphasic study of Chryseobacterium strains isolated from diseased aquatic animals
}

\author{
Jean Francois J. F. Bernardet, M. Vancanneyt, O. Matte-Tailliez, L. Grisez, \\ L. Grisez, Patrick Tailliez, Chantal Bizet, M. Nowakowski, Brigitte Kerouault, \\ J. Swings
}

\section{To cite this version:}

Jean Francois J. F. Bernardet, M. Vancanneyt, O. Matte-Tailliez, L. Grisez, L. Grisez, et al.. Polyphasic study of Chryseobacterium strains isolated from diseased aquatic animals. Systematic and Applied Microbiology, 2005, 28 (7), pp.640-660. 10.1016/j.syapm.2005.03.016 . hal-02681942

\section{HAL Id: hal-02681942 https://hal.inrae.fr/hal-02681942}

Submitted on 1 Jun 2020

HAL is a multi-disciplinary open access archive for the deposit and dissemination of scientific research documents, whether they are published or not. The documents may come from teaching and research institutions in France or abroad, or from public or private research centers.
L'archive ouverte pluridisciplinaire HAL, est destinée au dépôt et à la diffusion de documents scientifiques de niveau recherche, publiés ou non, émanant des établissements d'enseignement et de recherche français ou étrangers, des laboratoires publics ou privés. 


\title{
Polyphasic study of Chryseobacterium strains isolated from diseased aquatic animals
}

\author{
J.-F. Bernardet ${ }^{\mathrm{a}, *}$, M. Vancanneyt ${ }^{\mathrm{b}}$, O. Matte-Tailliez ${ }^{\mathrm{a}}$, L. Grisez ${ }^{\mathrm{c}, 1}$, P. Tailliez ${ }^{\mathrm{d}}$, \\ C. Bizet ${ }^{\mathrm{e}}$, M. Nowakowski ${ }^{\mathrm{e}}$, B. Kerouault ${ }^{\mathrm{a}}, \mathrm{J}_{\text {. Swings }}{ }^{\mathrm{b}}$ \\ ${ }^{a}$ Institut National de la Recherche Agronomique, Unité de Virologie et Immunologie Moléculaires, Jouy-en-Josas, France \\ ${ }^{\mathrm{b}}$ Ghent University, BCCM/LMG Bacteria Collection, Laboratorium voor Microbiologie, Ghent, Belgium \\ ${ }^{\mathrm{c}}$ Zoological Institute, Laboratory for Ecology and Aquaculture, Leuven, Belgium \\ dinstitut National de la Recherche Agronomique, Université Montpellier II, Unité d' Ecologie Microbienne des Insectes et \\ Interactions Hôte-pathogène, Montpellier, France \\ ${ }^{\mathrm{e}}$ Institut Pasteur, Département Structure et Dynamique des Génomes, Collection de l'Institut Pasteur, Paris, France
}

Received 11 March 2004

\section{Summary}

Members of most Chryseobacterium species occur in aquatic environments or food products, while strains of some other species are pathogenic to humans and animals. A collection of 52 Chryseobacterium sp. strains isolated from diseased fish, one frog isolate and 22 reference strains were included in a polyphasic taxonomy study. Fourteen clusters of strains were delineated following the comparison of whole-cell protein profiles. Most of these clusters were confirmed when the phenotypic and RAPD profiles and the 16S rRNA gene sequences were compared. Fatty acid composition helped differentiate the Chryseobacterium strains from members of related genera. None of the fish isolates could be allocated to the two species previously reported from fish but two isolates belonged to C. joostei, while the frog isolate was identified as Elizabethkingia meningoseptica, a human pathogen previously included in the genus Chryseobacterium. Three clusters grouping from 3 to 13 isolates will probably constitute the core of new Chryseobacterium species but all other isolates occupied separate or uncertain positions in the genus. This study further demonstrated the overall high similarity displayed by most Chryseobacterium strains whatever the technique used and the resulting difficulty in delineating new species in the genus. Members of this bacterial group should be considered potential emergent pathogens in various fish and frog species, farming conditions and geographical areas.

(C) 2005 Elsevier GmbH. All rights reserved.

Keywords: Chryseobacterium; Elizabethkingia; Fish disease; Frog disease; Polyphasic taxonomy; Phenotypic characteristics; Randomly amplified polymorphic DNA; Whole-cell protein profiles; SDS-PAGE; Fatty acid analysis; 16S rRNA gene sequence

\footnotetext{
Abbreviation: RAPD, randomly amplified polymorphic DNA

*Corresponding author. Tel.: + 33134652587 ;

fax: +33134652591 .

E-mail address: jean-francois.bernardet@jouy.inra.fr (J.-F. Bernardet).

${ }^{1}$ Current address: Intervet Norbio Singapore Pte Ltd., Singapore.
}

\section{Introduction}

The genus Chryseobacterium was proposed to accomodate six bacterial species previously included in the genus Flavobacterium [41]. Following an extensive 
polyphasic study, the whole group of organisms related to the genera Chryseobacterium and Flavobacterium was included in the family Flavobacteriaceae [4,5]. The genus Chryseobacterium currently comprises nine valid species and a non-valid one representing a variety of ecological niches $[3,20-22,41,44,46]$. Five species, namely $C$. indoltheticum [10], C. defluvii [21], "C. proteolyticum" [44], C. formosense [46] and $C$. daecheongense [22] were isolated from various soil and aquatic environments. Chryseobacterium spp. strains are also part of the psychrotrophic and proteolytic bacterial population that causes a variety of defects in food products such as processed meats, chilled fish and shellfish, and dairy products $[14,18]$. The polyphasic study of a group of dairy isolates recently resulted in the description of $C$. joostei $[19,20]$. Other Chryseobacterium species are pathogenic to humans and animals. Chryseobacterium gleum and $C$. indologenes may cause nosocomial infections in humans, usually in neonates or immunocompromised patients; they can also be retrieved from hospital environments and equipments and are usually resistant to many disinfectants and antibiotics [3]. The $16 \mathrm{~S}$ rRNA gene sequences of the putative new clinical species "C. massiliae" and "Candidatus Chryseobacterium timonae" have recently been deposited in GenBank [12]. Finally, C. balustinum [6,16] and C. scophthalmum $[28,29]$ were isolated from diseased fish. Chryseobacterium spp. strains were also detected among the bacterial flora in the gut of insects by direct amplification and sequencing of 16S rRNA genes [13], but they have not been fully characterized. Until recently, two more bacterial species were allocated to the genus Chryseobacterium, i.e. C. meningosepticum and C. miricola. However, owing to their separate position compared to other Chryseobacterium species in 16S rRNA gene sequence comparison studies, their transfer to the new genus Elizabethkingia was proposed [23]. Hence, the new combinations Elizabethkingia meningoseptica and E. miricola will be used thereafter. The latter species was isolated from condensation water in the space sation Mir [25] whereas the former is considered the most serious human pathogen in the group [3]. Since E. meningoseptica was also isolated from diseased birds [39], frogs, turtles and cats [11,15 and references therein,26], it may be the agent of zoonotic infections.

Over the last few years, fish pathology laboratories in Europe (Belgium, Finland, France) and Asia (Taiwan, Singapore) have isolated an increasing number of bacterial strains that shared the basic phenotypic characteristics of the genus Chryseobacterium and that were tentatively identified as Chryseobacterium sp., $C$. indologenes or $E$. meningoseptica using commercial identification galleries. In this paper, we present the results of the polyphasic study [42] of 52 fish isolates and one frog isolate.

\section{Materials and methods}

\section{Bacterial strains}

The bacterial strains used in this study are listed in Table 1. Except one frog isolate, all isolates were retrieved from diseased fish between 1994 and 2001. The host fish represented a variety of fish species, farming conditions, and geographical origins. About one-third of the strains were isolated from superficial lesions in otherwise apparently healthy fish while the other strains were isolated from internal organs of fish or frog suffering from hemorrhagic septicemia. Bacterial strains were isolated from samples inoculated on trypticase soy agar (bioMérieux sa, Marcy-$1^{\prime}$ Étoile, France) incubated at 22 or $26^{\circ} \mathrm{C}$ for 3 days. After the basic common characteristics (i.e., Gramnegative, non-motile rods, producing bright yelloworange flexirubin type pigments, a strong smell, catalase and oxidase, and yielding a Chryseobacterium spp. profile in API $20 \mathrm{E}$ and $20 \mathrm{NE}$ galleries) of these strains were identified, a retrospective screening of the culture collection of the Unité de Virologie et Immunologie Moléculaires yielded three poorly characterized fish isolates (i.e., JIP 105/82, JIP 108/ 83, and SAVU 12/90), tentatively labelled "Flavo bacterium-like" or "Flavobacterium sp." at the time of preservation, that shared the same basic characteristics and were consequently included in the study. The type strain of six valid Chryseobacterium species and of E. meningoseptica were also studied, as well as a second strain of each species. In the particular case of $C$. scophthalmum, a very high DNA homology had been demonstrated previously between the seven strains available [29]. Hence, all seven strains were included in this study in order to test the repeatability of the techniques used there after as well as their ability to reveal intra-specific variability. Since Bergeyella zoohelcum, Riemerella anatipestifer and $R$. columbina [40,41] form a distinct separate branch together with the Chryseobacterium and Elizabethkingia species in published 16S rRNA gene sequence similarity dendrograms [e.g., $3,4,20,22,25]$, the type strains of these three species were also included in the study. The other members of the Chryseobacterium-Elizabethkingia-RiemerellaBergeyella branch were not studied, either because they were published after this study was completed (C. defluvii [21], C. formosense [46], C. daecheongense [22], E. miricola [25], Kaistella koreensis [24], Sejongia antarctica and S. jeonii [45]) or because they were not available ("Haloanella gallinarum" [Pham, unpublished] and "Chryseobacterium proteolyticum" [44]). However, their 16S rRNA gene sequences were included in the phylogenetic study (see below). 
Table 1. Bacterial strains included in this study

\begin{tabular}{|c|c|c|c|c|}
\hline Name as received & Strain $^{\mathrm{a}}$ & Cluster number ${ }^{\mathrm{b}}$ & $\begin{array}{l}\text { Sequence } \\
\text { number }^{c}\end{array}$ & Source $^{\mathrm{d}}$ \\
\hline Elizabethkingia meningoseptica & $\begin{array}{l}\text { LMG } 4027^{\mathrm{T}} \\
\text { CIP } 60.57^{\mathrm{T}}\end{array}$ & 11 & AY468445 & $\begin{array}{l}\text { Cerebrospinal fluid, premature infant, } \\
\text { Massachusetts, USA, } 1949\end{array}$ \\
\hline Elizabethkingia meningoseptica & LMG 12280 & 11 & AY468480 & $\begin{array}{l}\text { Blood, newborn infant, Florida, USA, } \\
1950\end{array}$ \\
\hline Chryseobacterium scophthalmum & $\begin{array}{l}\text { LMG } 13028^{\mathrm{T}} \\
\text { CIP } 104199^{\mathrm{T}}\end{array}$ & 12 & & $\begin{array}{l}\text { Gills, juvenile turbot (Scophthalmus } \\
\text { maximus) with hemorrhagic septicemia, } \\
\text { Scotland, UK, } 1987\end{array}$ \\
\hline Chryseobacterium scophthalmum & LMG 13029 & 12 & & $\begin{array}{l}\text { Gills, diseased turbot, Scotland, UK, } \\
1987\end{array}$ \\
\hline Chryseobacterium scophthalmum & LMG 13030 & 12 & & Diseased turbot, Scotland, UK, 1987 \\
\hline Chryseobacterium scophthalmum & LMG 13031 & 12 & & Diseased turbot, Scotland, UK, 1987 \\
\hline Chryseobacterium scophthalmum & LMG 13032 & 12 & & Seawater, Scotland, UK, 1987 \\
\hline Chryseobacterium scophthalmum & LMG 13033 & 12 & & Seawater, Scotland, UK, 1987 \\
\hline Chryseobacterium scophthalmum & LMG 13034 & 12 & & $\begin{array}{l}\text { Gills, diseased turbot, Scotland, UK, } \\
1987\end{array}$ \\
\hline Chryseobacterium balustinum & $\begin{array}{l}\text { LMG } 8329^{\mathrm{T}} \\
\text { CIP } 103103^{\mathrm{T}}\end{array}$ & & AY468447 & $\begin{array}{l}\text { Heart blood, dace (Leuciscus leuciscus), } \\
\text { Dordogne river, Aquitaine, France, } 1959\end{array}$ \\
\hline Chryseobacterium balustinum & LMG 12856 & 5 & AY468481 & Water, hospital, London, UK, 1978 \\
\hline Chryseobacterium indoltheticum & $\begin{array}{l}\text { LMG } 4025^{\mathrm{T}} \\
\text { CIP } 103168^{\mathrm{T}}\end{array}$ & 10 & AY468448 & Marine mud \\
\hline Chryseobacterium indoltheticum & LMG 13342 & 10 & AY468444 & London, UK \\
\hline Chryseobacterium gleum & $\begin{array}{l}\text { LMG } 8334^{\mathrm{T}} \\
\text { CIP } 103039^{\mathrm{T}}\end{array}$ & 14 & AY468449 & High vaginal swab, London, UK, 1979 \\
\hline Chryseobacterium gleum & LMG 12450 & 14 & & Wound swab, London, UK \\
\hline Chryseobacterium indologenes & $\begin{array}{l}\text { LMG } 8337^{\mathrm{T}} \\
\text { CIP } 101026^{\mathrm{T}}\end{array}$ & 5 & AY468450 & Human trachea at autopsy, 1958 \\
\hline Chryseobacterium indologenes & LMG 12452 & 5 & & No data available \\
\hline Chryseobacterium joostei & $\begin{array}{l}\text { LMG } 18212^{\mathrm{T}} \\
\text { CIP } 105533^{\mathrm{T}}\end{array}$ & 3 & & $\begin{array}{l}\text { Raw cow milk, Ixopo district, Kwazulu- } \\
\text { Natal, South Africa, } 1981\end{array}$ \\
\hline Chryseobacterium joostei & LMG 18208 & 3 & AY468479 & $\begin{array}{l}\text { Raw cow milk, Heidelberg district, } \\
\text { Transvaal, South Africa, } 1981\end{array}$ \\
\hline Bergeyella zoohelcum & $\begin{array}{l}\text { LMG } 8351^{\mathrm{T}} \\
\text { CIP } 103041^{\mathrm{T}}\end{array}$ & & & Human sputum, Nebraska, USA \\
\hline Riemerella anatipestifer & $\begin{array}{l}\text { LMG } 11054^{\mathrm{T}} \\
\text { CIP } 82.28^{\mathrm{T}}\end{array}$ & & & Duck blood, USA \\
\hline \multirow[t]{3}{*}{ Riemerella columbina } & $\begin{array}{l}\text { LMG } 11607^{\mathrm{T}} \\
\text { CIP } 106288^{\mathrm{T}}\end{array}$ & & & Pigeon palatine cleft, Germany, 1989 \\
\hline & JIP $105 / 82$ & & AY468457 & $\begin{array}{l}\text { Skin lesion, Koi carp, (Cyprinus carpio), } \\
\text { Ile-de-France, France, } 1982 \text { (Japan) }\end{array}$ \\
\hline & JIP $108 / 83$ & & AY468458 & $\begin{array}{l}\text { Extensive skin ulcer, snakehead (Channa } \\
\text { sp.), France, } 1983 \text { (Thailand) }\end{array}$ \\
\hline
\end{tabular}


Table 1. (continued)

\begin{tabular}{|c|c|c|c|c|}
\hline Name as received & Strain $^{\mathrm{a}}$ & Cluster number ${ }^{\mathrm{b}}$ & $\begin{array}{l}\text { Sequence } \\
\text { number }\end{array}$ & Source $^{\mathrm{d}}$ \\
\hline & SAVU $12 / 90$ & & AY468459 & $\begin{array}{l}\text { Skin lesion, sea bass (Dicentrarchus } \\
\text { labrax), Mediterranean coast, France, } \\
1990\end{array}$ \\
\hline & UOF CO294 & & AY427792 & $\begin{array}{l}\text { Gills, brown trout (Salmo trutta), } \\
\text { Finland, } 1994\end{array}$ \\
\hline & $\begin{array}{l}\text { UOF CR694 } \\
\text { LMG } 22906 \\
\text { CIP } 108621\end{array}$ & 3 & & $\begin{array}{l}\text { Tail lesion, Atlantic salmon (Salmo } \\
\text { salar), Finland, } 1994\end{array}$ \\
\hline & $\begin{array}{l}\text { UOF CR } 1094 \\
\text { LMG } 22907 \\
\text { CIP } 108622\end{array}$ & 3 & AY468451 & $\begin{array}{l}\text { Deep ulcerative dorsal lesion, Atlantic } \\
\text { salmon, Finland, } 1994\end{array}$ \\
\hline & UOF CM295 & & AY468452 & Kidney, brown trout, Finland, 1995 \\
\hline & UOF CM895 & & AY468453 & Kidney, Atlantic salmon, Finland, 1995 \\
\hline & UOF CR2995 & 4 & AY468454 & $\begin{array}{l}\text { Deep ulcerative dorsal lesion, Atlantic } \\
\text { salmon, Finland, } 1995\end{array}$ \\
\hline & UOF CR4395 & 4 & AY468455 & $\begin{array}{l}\text { Peduncle lesion, Atlantic salmon, } \\
\text { Finland, } 1995\end{array}$ \\
\hline & UOF CR4095 & & AY468483 & $\begin{array}{l}\text { Deep ulcerative dorsal lesion, Atlantic } \\
\text { salmon, Finland, } 1995\end{array}$ \\
\hline & $\begin{array}{l}\text { UOF CO496 } \\
\text { LMG } 22914 \\
\text { CIP } 108623\end{array}$ & 6 & & Jaw erosion, brown trout, Finland, 1996 \\
\hline & $\begin{array}{l}\text { UOF CM1396 } \\
\text { LMG } 22905 \\
\text { CIP } 108620\end{array}$ & 6 & AY468456 & Kidney, Atlantic salmon, Finland, 1996 \\
\hline & $\begin{array}{l}\text { UOF CM1996 } \\
\text { LMG } 22915 \\
\text { CIP } 108624\end{array}$ & 6 & & Kidney, Atlantic salmon, Finland, 1996 \\
\hline & UOF CM1796 & & & Kidney, brown trout, Finland, 1996 \\
\hline & ZIL K4U & 1 & & Skin ulcer, Koi carp, Belgium, 1996 \\
\hline & ZIL K5U & 1 & & Skin ulcer, Koi carp, Belgium, 1996 \\
\hline & ZIL K5M1 & 1 & & Muscle lesion, Koi carp, Belgium, 1996 \\
\hline & ZIL K5M2 & 1 & & Muscle lesion, Koi carp, Belgium, 1996 \\
\hline & ZIL K5BV & 1 & & Skin ulcer, Koi carp, Belgium, 1996 \\
\hline & $\begin{array}{l}\text { ZIL K } 3.2 \\
\text { LMG } 19173 \\
\text { CIP } 108619\end{array}$ & 1 & AJ874979 & $\begin{array}{l}\text { Tail lesion, Koi carp, Belgium, } 1996 \\
\text { (Japan) }\end{array}$ \\
\hline & ZIL K4.3 & 1 & & $\begin{array}{l}\text { Tail lesion, Koi carp, Belgium, } 1996 \\
\text { (Japan) }\end{array}$ \\
\hline & ZIL K6.1 & 1 & & $\begin{array}{l}\text { Skin lesion, Koi carp, Belgium, } 1996 \\
\text { (Japan) }\end{array}$ \\
\hline & ZIL K12.1 & 1 & & $\begin{array}{l}\text { Mouth lesion, Koi carp, Belgium, } 1996 \\
\text { (Japan) }\end{array}$ \\
\hline
\end{tabular}


Table 1. (continued)

\begin{tabular}{|c|c|c|c|c|}
\hline \multirow[t]{2}{*}{ Name as received } & Strain $^{\mathrm{a}}$ & Cluster number ${ }^{\mathrm{b}}$ & $\begin{array}{l}\text { Sequence } \\
\text { number }\end{array}$ & Source $^{\mathrm{d}}$ \\
\hline & ZIL K13.1 & \multicolumn{2}{|l|}{1} & $\begin{array}{l}\text { Mouth lesion, Koi carp, Belgium, } 1996 \\
\text { (Japan) }\end{array}$ \\
\hline & \multicolumn{2}{|l|}{ JIP 16/96 } & AY468460 & $\begin{array}{l}\text { Internal organs, dwarf gourami (Colisa } \\
\text { lalia), France, } 1996 \text { (Singapore) }\end{array}$ \\
\hline & $\begin{array}{l}\text { JIP } 17 / 96 \\
\text { LMG } 22908 \\
\text { CIP } 108646\end{array}$ & 2 & AY468461 & $\begin{array}{l}\text { Kidney, leopard corydoras (Corydoras } \\
\text { julii), France, } 1996 \text { (USA) }\end{array}$ \\
\hline & LPAA 3120 & 9 & AY468462 & $\begin{array}{l}\text { Skin lesion, rainbow trout (Oncorhynchus } \\
\text { mykiss), Brittany, France, } 1996\end{array}$ \\
\hline & LPAA 3230 & 9 & & $\begin{array}{l}\text { Skin lesion, rainbow trout, Brittany, } \\
\text { France, } 1996\end{array}$ \\
\hline & \multicolumn{2}{|l|}{ FRGDSA 1502/97 } & AY468463 & $\begin{array}{l}\text { Kidney, sturgeon (Acipenser sturio), } \\
\text { Landes, France, } 1997\end{array}$ \\
\hline & \multicolumn{2}{|l|}{ FRGDSA 4034/97 } & AY468464 & $\begin{array}{l}\text { Skin ulcer, rainbow trout, Landes, } \\
\text { France, } 1997\end{array}$ \\
\hline & \multicolumn{2}{|l|}{ FRGDSA 4580/97 } & AY468465 & $\begin{array}{l}\text { Siberian sturgeon (Acipenser baeri) fry, } \\
\text { Landes, France, } 1997\end{array}$ \\
\hline & LDA39 G1966 4a & 13 & AY468466 & $\begin{array}{l}\text { Skin lesion, Asian catfish (Pangasius } \\
\text { bocourti), Kompong Chhnang, } \\
\text { Cambodia, } 1997\end{array}$ \\
\hline & LDA39 G1966 12a & 13 & AY468467 & $\begin{array}{l}\text { Fin lesion, Asian catfish (Pangasianodon } \\
\text { hypophthalmus), Kompong Chhnang, } \\
\text { Cambodia, } 1997\end{array}$ \\
\hline & LDA39 G1966 12c & 13 & AY468468 & $\begin{array}{l}\text { Spleen, Asian catfish (Pangasianodon } \\
\text { hypoph-thalmus), Kompong Chhnang, } \\
\text { Cambodia, } 1997\end{array}$ \\
\hline & LDA39 G1966 13a & 13 & AY468469 & $\begin{array}{l}\text { Skin lesion, walking catfish (Clarias sp.), } \\
\text { Kompong Chhnang, Cambodia, } 1997\end{array}$ \\
\hline & $\begin{array}{l}\text { FRGDSA } 11 / 99 \\
\text { LMG } 22909 \\
\text { CIP } 108647\end{array}$ & 1 & & $\begin{array}{l}\text { Skin ulcer, Koi carp, Landes, France, } \\
1999\end{array}$ \\
\hline & LDVH 33/99 & 8 & AY468470 & $\begin{array}{l}\text { Goldfish (Carassus auratus), Hérault, } \\
\text { France, } 1999 \text { (P. R. China) }\end{array}$ \\
\hline & LDVH 1 & & AY468472 & $\begin{array}{l}\text { Internal organs, goldfish, Hérault, } \\
\text { France, } 2000 \text { (P. R. China) }\end{array}$ \\
\hline & $\begin{array}{l}\text { LDVH } 2 \\
\text { LMG } 22910 \\
\text { CIP } 108648\end{array}$ & 1 & & $\begin{array}{l}\text { Internal organs, Koi carp, Hérault, } \\
\text { France, } 2000 \text { (Japan) }\end{array}$ \\
\hline & LDVH 3 & 8 & AY468484 & $\begin{array}{l}\text { Skin ulcer, goldfish, Hérault, France, } \\
2000 \text { (Italy) }\end{array}$ \\
\hline & LDVH 4 & 8 & AY468473 & $\begin{array}{l}\text { Internal organs, goldfish, Hérault, } \\
\text { France, } 2000\end{array}$ \\
\hline & $\begin{array}{l}\text { LDVH } 5 \\
\text { LMG } 22911 \\
\text { CIP } 108649\end{array}$ & 1 & & $\begin{array}{l}\text { Internal organs, goldfish, Hérault, } \\
\text { France, } 2000 \text { (Italy) }\end{array}$ \\
\hline
\end{tabular}


Table 1. (continued)

\begin{tabular}{|c|c|c|c|c|}
\hline \multirow[t]{2}{*}{ Name as received } & Strain $^{\mathrm{a}}$ & Cluster number ${ }^{\mathrm{b}}$ & $\begin{array}{l}\text { Sequence } \\
\text { number }^{c}\end{array}$ & Source $^{\mathrm{d}}$ \\
\hline & LDVH $42 / 00$ & 7 & AY468475 & $\begin{array}{l}\text { Internal organs, Malawi lake Cichlid, } \\
\text { Hérault, France, } 2000\end{array}$ \\
\hline & $\begin{array}{l}\text { LDVH } 43 / 00 \\
\text { LMG } 22912 \\
\text { CIP } 108650\end{array}$ & 2 & AY468476 & $\begin{array}{l}\text { Internal organs, kuhli loach } \\
\text { (Acanthophthalmus kuhlii), Hérault, } \\
\text { France, } 2000\end{array}$ \\
\hline & $\begin{array}{l}\text { LDVH } 44 / 00 \\
\text { LMG } 22913 \\
\text { CIP } 108651\end{array}$ & 2 & & $\begin{array}{l}\text { Internal organs, Malawi lake Cichlid, } \\
\text { Hérault, France, } 2000\end{array}$ \\
\hline & LDVH $45 / 00$ & 7 & & $\begin{array}{l}\text { Internal organs, Malawi lake Cichlid, } \\
\text { Vosges, France, } 2000\end{array}$ \\
\hline & JG-Torno & & AY468471 & Liver, rainbow trout, Spain, 2000 \\
\hline & JG-2 & & & $\begin{array}{l}\text { Skin lesion, rainbow trout, Asturias, } \\
\text { Spain, } 2000\end{array}$ \\
\hline & JIP 13/00 (2) & & AY468474 & $\begin{array}{l}\text { Muscle lesion, neon tetra (Paracheirodon } \\
\text { innesi), France, } 2000 \text { (Hong Kong) }\end{array}$ \\
\hline & JIP 06/01 (1) & & AY468446 & $\begin{array}{l}\text { Internal organs, rainbow trout, Yvelines, } \\
\text { France, } 2001\end{array}$ \\
\hline & $\begin{array}{l}\text { NTU 870424-IL } \\
\text { CIP } 108652\end{array}$ & 11 & AY468477 & $\begin{array}{l}\text { Internal organs, cultured bullfrog (Rana } \\
\text { catesbeiana) with hemorrhagic } \\
\text { septicemia, Taiwan, } 1986\end{array}$ \\
\hline & LMG 19914 & & AY468478 & $\begin{array}{l}\text { Apparently healthy cultured European } \\
\text { eel (Anguilla anguilla), Belgium }\end{array}$ \\
\hline
\end{tabular}

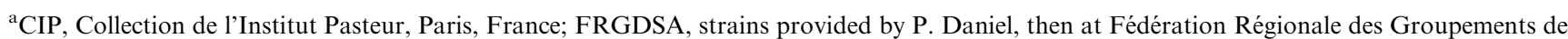
Défense Sanitaire d'Aquitaine, Section Aquacole, Mont-de-Marsan, France; JG, strains provided by J.A. Guijarro, University of Oviedo, Oviedo, Spain; JIP, culture collection of the Unité de Virologie et Immunologie Moléculaires, Institut National de la Recherche Agronomique, Jouy-en-Josas, France; LDA39, strains isolated by P. Girard and provided by M. Morand, Laboratoire Départemental d'Analyses du Jura, Lons-le-Saunier, France; LDVH, strains provided by N. Keck, Laboratoire Départemental Vétérinaire de l'Hérault, Montpellier, France; LMG, BCCM/LMG Bacteria Collection, Laboratorium voor Microbiologie, Ghent University, Ghent, Belgium; LPAA, strains provided by A. Abiven, Agence Française pour la Sécurité Sanitaire des Aliments Site de Brest, Laboratoire d'Études et de Recherches en Pathologie des Poissons, Plouzané, France; NTU, strain provided by H.-Y. Chung, National Taiwan University, Taipei, Taiwan; SAVU, strain provided by J.-C. Raymond, Service Aquacole Vétérinaire d'Urgence, Montpellier, France; UOF, strains provided by P. Rintamäki-Kinnunen, Department of Biology, University of Oulu, Oulu, Finland; ZIL, culture collection of the Laboratory for Ecology and Aquaculture, Zoological Institute, Leuven, Belgium.

${ }^{\mathrm{b}}$ Numbers of the clusters that emerged from SDS-PAGE analysis (Fig. 2).

${ }^{\mathrm{c}}$ Only those 16S rRNA gene sequences that were determined in the course of this study are listed.

${ }^{\mathrm{d}}$ Fish isolates are listed according to their year of isolation. The country where each strain was isolated is cited; for recently imported ornamental fish, the name of the country of origin is specified in parentheses when available.

\section{Culture conditions and phenotypic study}

All strains were cultivated on nutrient (Difco, Becton Dickinson Microbiology Systems, Sparks, MD) or trypticase soy agar or in the corresponding broth at $26^{\circ} \mathrm{C}$, unless otherwise stated. The minimal standards proposed for describing new taxa of the family Flavobacteriaceae [4] were followed.

The morphology (i.e., shape, size, aspect of the edge, color), odor and consistency of the colonies were recorded. Twenty-four-hour cultures in Anacker and Ordal's broth [1] were used to test bacterial motility using the hanging drop method and phase-contrast microscopy, to perform the Gram staining, and to record the bacterial morphology. The presence of flexirubin type pigments was tested by observing the color shift when a small mass of bacterial cells collected on agar and deposited on a glass slide was flooded with a $20 \%(\mathrm{w} / \mathrm{v}) \mathrm{KOH}$ aqueous solution $[4,31]$. The type of respiratory metabolism was determined by inoculating 
deep tubes of meat-liver medium containing 6\% agar (BIO-RAD, Marnes-la-Coquette, France). The following characteristics were tested according to West and Colwell [43]: hydrolysis of sodium alginate; hydrolysis of starch, deoxyribonucleic acid, gelatin and Tween 80 (tested both on plain nutrient agar [containing $0.5 \%$ $\mathrm{NaCl}]$ and on the same medium enriched to $1.5 \%$ $\mathrm{NaCl}$; production of indole; reduction of nitrate; and growth in $0.5 \%, 1.5 \%, 3 \%, 6 \%, 8 \%$, and $10 \% \mathrm{NaCl}$ nutrient broth. The oxidase reaction was performed on oxidase test discs (bioMérieux sa) and the presence of catalase was assessed using $3 \%(\mathrm{v} / \mathrm{v}) \mathrm{H}_{2} \mathrm{O}_{2}$. Hemolysis was recorded on trypticase soy agar supplemented with $5 \%(\mathrm{v} / \mathrm{v})$ sheep blood (bioMérieux sa). Trypticase soy agar was also used to test the temperature tolerance at 5 , 26,37 , and $42^{\circ} \mathrm{C}$. Bacterial growth was tested on the following solid media: MacConkey no. 3 (Oxoid Limited, Basingstoke, England), thiosulfate-citratebile-sucrose (TCBS; Difco), brain-heart infusion (Difco), Mueller Hinton (Difco), marine 2216 (Difco), and cetrimide [9]. The following tests were performed according to Barrow and Feltham [2]: fermentative versus oxidative metabolism of glucose $(\mathrm{O} / \mathrm{F}$ test); presence of arginine dihydrolase and of lysine and ornithine decarboxylases; hydrolysis of L-tyrosine and pigment production on $0.5 \%$ L-tyrosine nutrient agar; formation of a precipitate on $10 \%$ egg yolk nutrient agar; and acid production from carbohydrates in ammonium salt medium (the following carbohydrates were tested at a 1\% final concentration: arabinose, cellobiose, glucose, ethanol, fructose, galactose, glycerol, lactose, maltose, mannitol, mannose, melibiose, saccharose, sorbitol, trehalose, and xylose). The following characteristics were tested according to Smibert and Krieg [35]: hydrolysis of aesculin and casein; methyl red test and Voges-Proskauer reaction; production of acid and alkaline phosphatases and of urease; and the reactions on Kliger iron agar (Difco), namely the fermentation of glucose and lactose and the production of gas and $\mathrm{H}_{2} \mathrm{~S}$. Hydrolysis of elastin was tested according to Hsu et al. [17]. Growth on sodium citrate as the sole source of carbon was tested on Simmons' citrate agar (Difco). The production of L-phenylalanine deaminase was tested using the technique of Richard and Kiredjian [32]. All tests were read after 3 days of incubation, except for the acidification of sugars, the utilisation of citrate on Simmons' citrate agar, the degradation of aesculin, the production of urease, and the growth at $4{ }^{\circ} \mathrm{C}$ and on the various agar media, which were scored after 1 week of incubation. The reactions in API 20E, 20NE, and ZYM galleries (bioMérieux sa) were assessed following the producer's prescriptions except for the incubation temperature $\left(26^{\circ} \mathrm{C}\right)$ and time $(48 \mathrm{~h})$. The sensitivity of all strains to a selection of antibiotics was also investigated; it is the subject of another paper [27].

\section{Biotype 100 galleries}

Utilization of carbon sources was investigated using Biotype 100 galleries (bioMérieux sa) that contained 99 pure carbon sources. A flask of Biotype medium 2 was inoculated with $2 \mathrm{ml}$ of a bacterial suspension in distilled water calibrated at McFarland density index 4. The cupules were filled with $400 \mu \mathrm{l}$ of inoculated medium and the galleries were incubated for 4 days at $30^{\circ} \mathrm{C}$. The galleries were checked daily for visible growth. Growth was scored visually by comparison with the aspect of the control cupule containing no carbon source. For the 10 strains that showed no visible growth at $30^{\circ} \mathrm{C}$, new galleries were inoculated and incubated at 25 or $37^{\circ} \mathrm{C}$.

\section{Analysis of phenotypic data}

Those characteristics that were positive or negative for all strains studied (see below) were not included in the analysis. Only those characteristics that gave variable results among the strains, and were thus considered discriminant, were included in the data analysis, with the following exceptions. Those characteristics that were tested using different methods or conditions (i.e., using a conventional procedure and one of the tests in API galleries, or on both plain and 1.5\% $\mathrm{NaCl}$ nutrient agar) yielding identical results for all strains studied were included only once. This was the case for the hydrolysis of aesculin and Tween 80, and for the production of urease and indole. Conversely, when some strains yielded different results for a given characteristic using different tests, the different sets of data were included in the analysis. For instance, the results of the ONPG, PNPG, and no. 14 tests (in API 20E, 20NE and ZYM galleries, respectively) for the detection of $\beta$-galactosidase were all included. Also deleted from the analysis were those tests that proved less sensitive (i.e., that yielded a lower number of positive results) than the other tests used to detect the same characteristic. Hence, the conventional tests for nitrate reduction, hydrolysis of gelatin, and production of acid and alkaline phosphatases, that proved less sensitive than their counterparts in API galleries, were deleted from the analysis. Conversely, the API 20E test for bacterial growth on Simmon's citrate, less sensitive than its conventional counterpart, was deleted. The API $20 \mathrm{E}$ test for gelatin hydrolysis detected a lower number of positive strains than the corresponding test in API 20NE galleries and was consequently deleted from the analysis. Also deleted were the conventional tests performed on $1.5 \% \mathrm{NaCl}$ nutrient agar for the hydrolysis of DNA and starch, since they were less sensitive than the same tests performed on plain nutrient agar. 
The 111 differential phenotypic characteristics included in the analysis were grouped as follows: Group 1: four different colony types (yellow, brown, small and mucous); Group 2: three different growth temperatures $\left(5,37\right.$ and $\left.42^{\circ} \mathrm{C}\right)$; Group 3: 17 conventionally tested biochemical characteristics (growth on Simmon's citrate and acidification of the 16 above-mentioned carbohydrates); Group 4: 10 other conventionally tested biochemical characteristics (production of flexirubin type pigment, brown pigment on tyrosine agar, precipitate on egg yolk agar and phenylalanine deaminase; and hydrolysis of casein, DNA, starch, Tween 80, elastin, and tyrosine); Group 5: degradation of 18 substrates in APY ZYM galleries (i.e., all substrates except naphthol-AS-BI- $\beta$-D-glucuronide); Group 6: 17 characteristics in API 20E (ONPG) and API 20NE (i.e., all tests except fermentation of glucose, production of arginine dihydrolase and assimilation of caprate and malate) galleries; Group 7: assimilation of 38 substrates in Biotype100 galleries; and Group 8: growth on/in four media (Mueller-Hinton, marine 2216 and cetrimide agars and $3 \% \mathrm{NaCl}$ nutrient broth). For analysis, the results were expressed as positive/negative (colony types, most conventional biochemical tests, and tests in API 20E, 20NE and Biotype 100 galleries), or as intensities from 0 to 3 (growth on different media and at different temperatures, hydrolysis of tyrosine and production of pigment on tyrosine agar, production of phenylalanine deaminase, and formation of a precipitate on egg yolk agar) or from 0 to 5 (API ZYM galleries). A distance matrix was calculated for each group of characteristics using the BioNumerics software (Applied Maths, Sint Martens-Latem, Belgium). The Gower similarity coefficient was used for non-binary data while the simple matching coefficient and the Jaccard coefficient were used for binary data. A resulting distance matrix was calculated using the eight individual matrices.

\section{Fatty acid methyl ester (FAME) analysis}

Cultures were grown for $24 \mathrm{~h}$ at $28^{\circ} \mathrm{C}$ on plates containing $30 \mathrm{~g}$ trypticase soy broth (BBL 11768, Becton Dickinson Microbiology Systems, Sparks, MD) supplemented with $15 \mathrm{~g}$ Bacto agar (Difco) per liter distilled water. Cells were saponified, methylated to fatty acid methyl esters (FAMEs) and extracted following the recommendations of the commercial identification system MIDI (Microbial Identification System Inc., Newark, DEL). Fatty acid methyl esters were separated on a Agilent 6890A Series Gas Chromatograph with 7683 autoinjector and autosampler tray module (Agilent Technologies). Separation of FAMEs was achieved with a fused-silica capillary column $(25 \mathrm{~m} \times 0.2 \mathrm{~mm})$ with cross-linked $5 \%$ phenylmethyl silicone (film thickness $0.33 \mu \mathrm{m}$; HP Ultra 2). $\mathrm{H}_{2}$ was serving as carrier gas.
Peak integration and identification was performed using the Hewlett-Packard Chemstation software (Hewlett-Packard $\mathrm{GmbH}$ ) and the MIDI software.

\section{Whole-cell protein analysis}

Whole-cell protein extracts were prepared and SDSPAGE was performed as described by Pot et al. [30]. Densitometric analysis, normalization and interpolation of protein profiles, and a numerical analysis (with the Pearson similarity coefficient and the unweighted pair group method using arithmetic averages [UPGMA]) were performed using the Gelcompar software package (Applied Maths, Sint Martens-Latem, Belgium), versions 3.1 and 4.0, respectively.

\section{Randomly amplified polymorphic DNA analysis}

Total cellular DNA of a 2-ml bacterial culture in late exponential growth phase was obtained using the Genomic DNA WIZARD Kit (Promega, Charbonnières-les-Bains, France). RAPD profiles were determined as described previously [37] using primers $\mathrm{P} 1\left(5^{\prime}\right.$ CTG CTG GGA C-3') and P2 (5'-CGC CCT GCC C-3') in separate reactions. For each strain, the two RAPD profiles were merged and the resulting patterns were compared using the GelCompar software package (see above)

\section{S rRNA gene sequencing}

The almost complete 16S rRNA gene of a selection of fish isolates and reference strains (see below) was amplified by PCR using two primers: 5'-AGAGTTTGATYCTGGCTC-3' (position 8 forward of the E. coli 16S rRNA gene sequence) [8] and 5'-CNCGTCC TTCATCGCCT-3' (position 44 reverse of the E. coli 23S rRNA gene sequence) [7]. Amplification conditions were: $96^{\circ} \mathrm{C}$ for $4 \mathrm{~min}$ followed by 30 cycles of $10 \mathrm{~s}$ at $96{ }^{\circ} \mathrm{C}, 30 \mathrm{~s}$ at $50{ }^{\circ} \mathrm{C}$, and $2 \mathrm{~min}$ at $72^{\circ} \mathrm{C}$. PCR products were purified by a WIZARD PCR Purification Kit (Promega). Three 500-600-bp overlapping sequences were obtained by using the purified 16S rRNA gene PCR fragment as the template and the following sequencing primers: 5'-TATGCATTTCACCKCTACA-3' (position 684 reverse), 5'-CTCGTTGCAGGACT TAAC-3' (position 1089 reverse) and 5'-GNTACCTT GTTACGACTT-3' (position 1492 reverse). The $16 \mathrm{~S}$ partial and overlapping sequences were assembled and the resulting sequences were compared using the neighbor-joining method [33] and the model of Jukes and Cantor included in the PAUP programme [36]. The bootstrap analysis was performed with 1000 data sets. 


\section{Results}

\section{Phenotypic study}

After 48 -h incubation at $26^{\circ} \mathrm{C}$ on trypticase soy agar, all strains produced shiny, smooth, circular, raised colonies with an entire edge. The colonies of most strains were $2-3 \mathrm{~mm}$ in diameter and colored bright yellow-orange by a non-diffusible, nonfluorescent, flexirubin type pigment. Conversely, the E. meningoseptica, B. zoohelcum, $R$. anatipestifer, and $R$. columbina reference strains, as well as the frog isolate NTU 87024 IL, produced very pale yellow or creamy-white colonies. The slightly darker, brownish orange pigment produced by the isolates UOF CR2995, UOF CR4395, and UOF CM1796 also belonged to the flexirubin type; numerous tiny crystals also grew in the agar under the colonies of the two former strains. These three strains, as well as the strain UOF CM895, produced smaller (i.e., about $1 \mathrm{~mm}$ in diameter) colonies than all other strains. The colonies of the strain LDVH 45/00 had a very mucous and ropy consistency, while those of all other strains had a creamy to butyrous consistency. Most strains emitted a rather strong, cheesy smell. Broth cultures were uniformly turbid. The cells of all strains were Gram-negative, uniformly shaped, non-sporeforming rods about $1-2 \mu \mathrm{m}$ long and $0.3-0.5 \mu \mathrm{m}$ wide with parallel sides and rounded ends. Neither gliding nor flagellar motility were observed.

All strains were positive for the following conventional tests: strictly aerobic metabolism; production of catalase and oxidase; growth in $0.5 \%$ and $1.5 \% \mathrm{NaCl}$ nutrient broth; growth at $26{ }^{\circ} \mathrm{C}$; oxidative metabolism of glucose in $\mathrm{O} / \mathrm{F}$ test; and growth on brain-heart infusion, trypticase soy, sheep blood trypticase soy, and nutrient agars. In API ZYM galleries, all strains hydrolyzed the following substrates to varying degrees: 2-naphthylphosphate, 2-naphthyl-caprylate, L-leucyl-2-naphthylamide, L-valyl-2-naphthylamide, 2-naphthyl-phosphate, and naphthol-AS-BI-phosphate. All strains were negative for the following conventional tests: methyl red test and Voges-Proskauer reaction; growth in $6 \%, 8 \%$, and $10 \% \mathrm{NaCl}$ nutrient broth; production of indole; fermentative metabolism of glucose in $\mathrm{O} / \mathrm{F}$ test; the four tests on Kliger iron agar; growth on MacConkey and TCBS agars; hydrolysis of sodium alginate; and hemolysis of sheep blood. All strains were also negative (i) for glucose fermentation, production of arginine dihydrolase, and assimilation of caprate and malate in API 20NE galleries; (ii) for the production of arginine dihydrolase, lysine and ornithine decarboxilases, $\mathrm{H}_{2} \mathrm{~S}$, tryptophane deaminase and acetoin (Voges-Proskauer test), and for the nine $\mathrm{O} / \mathrm{F}$ reactions in API $20 \mathrm{E}$ galleries; and (iii) for the hydrolysis of naphthol-AS-BI$\beta$-D-glucuronide in API ZYM galleries. The results differed among the strains for all other tests, either conventional or included in API galleries. In Biotype 100 galleries, the type strains of $B$. zoohelcum, $R$. anatipestifer and $R$. columbina, as well as the fish isolates UOF CM895, UOF CM1796 and FRGDSA $4034 / 97$ were unable to assimilate any of the 99 substrates whatever the temperature used. All other strains were able to assimilate from 4 up to 22 substrates in Biotype 100 galleries; in all, 38 substrates out of 99 were assimilated by at least one strain.

The results of the analysis of phenotypic data are presented as a dendrogram calculated by unweighted pair group average linkage (UPGMA) (Fig. 1).

\section{Comparison of whole-cell protein patterns, randomly amplified polymorphic DNA patterns and phenotypic characteristics}

The results of the SDS-PAGE analysis of protein profiles of all strains studied are presented in Fig. 2 and those of the RAPD analysis in Fig. 3. The comparison of Figs. 1-3 showed that some fish isolates and reference strains were clustered whereas the others exhibited independent profiles and occupied isolated positions in the dendrograms. Fourteen clusters comprising 2-13 strains were most distinctly delineated in SDS-PAGE, while RAPD either confirmed some clusters (i.e., 1, 2, 5, $7,9,12$ and 14) or differentiated the isolates within others (clusters 3, 4, 6, 8, 10, 11 and 13). Identical RAPD profiles were displayed by the isolates sharing the same origin (e.g., the 10 ZIL isolates, the $7 C$. scophthalmum strains, and the members of clusters 7 and 9) and even by some strains whose origins were different (e.g., the members of clusters 1, 2, 5, 6 and 14). Conversely, some isolates displayed different RAPD profiles though sharing a common origin (e.g., the four LDA39 G1966 strains and the five UOF CR strains). The phenotypic study confirmed the clustering resulting from the comparison of protein profiles, except for clusters $1,2,3,5,12$ and 14 whose members displayed varying degrees of phenotypic heterogeneity (Fig. 1). Some clusters were delineated in the same way by the SDS-PAGE and phenotypic analyses (i.e., clusters 4, 10, 11 and 13) or by the SDS-PAGE and RAPD analyses (clusters 1, 2, 5, 12 and 14), while clusters 7, 8 and 9 were delineated in the same way by all three methods. Cluster delineation was made difficult by the overall high similarity of most isolates and reference strains in all techniques used.

\section{FAME analysis}

All fish isolates also shared an overall very similar fatty acid composition, consistent with that of the reference strains of most Chryseobacterium species and of B. zoohelcum (Table 2) and with published data for 
$66 \quad 687072747678 \quad 80828486889092949698100$

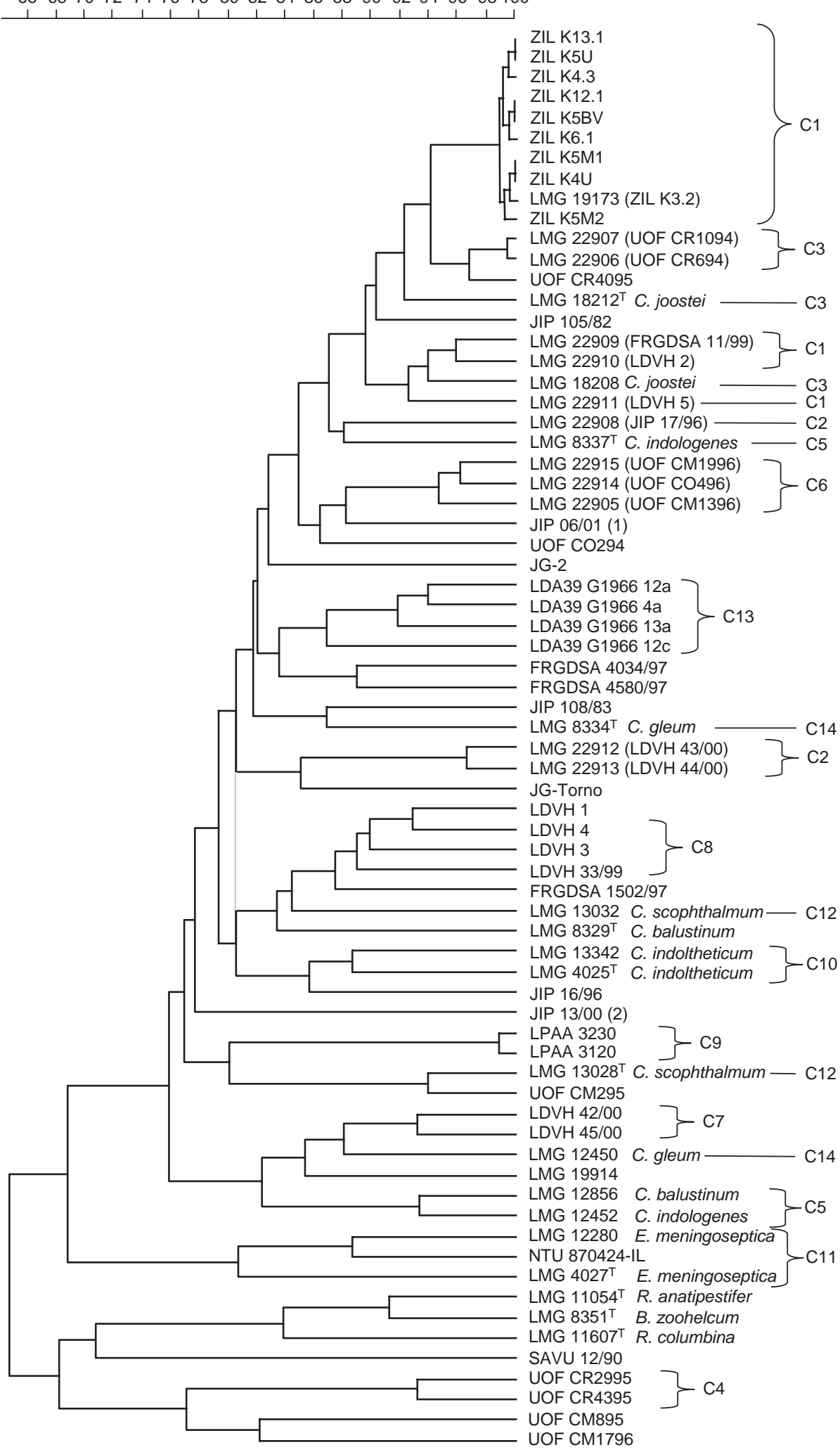

Fig. 1. Comparison of the 111 differential phenotypic characteristics of the 70 bacterial strains studied (only two among the seven $C$. scophthalmum strains were included in the phenotypic analysis) and deduced dendrogram obtained by the unweighted pair group method using arithmetic averages (UPGMA). A distance matrix was calculated for each group of characteristics. The eight distance matrices were then combined using the BioNumerics software. The scale bar indicates the correlation values $(\times 100)$. The position of members of the clusters (C1-C14) that emerged from SDS-PAGE analysis (Fig. 2) is indicated. 


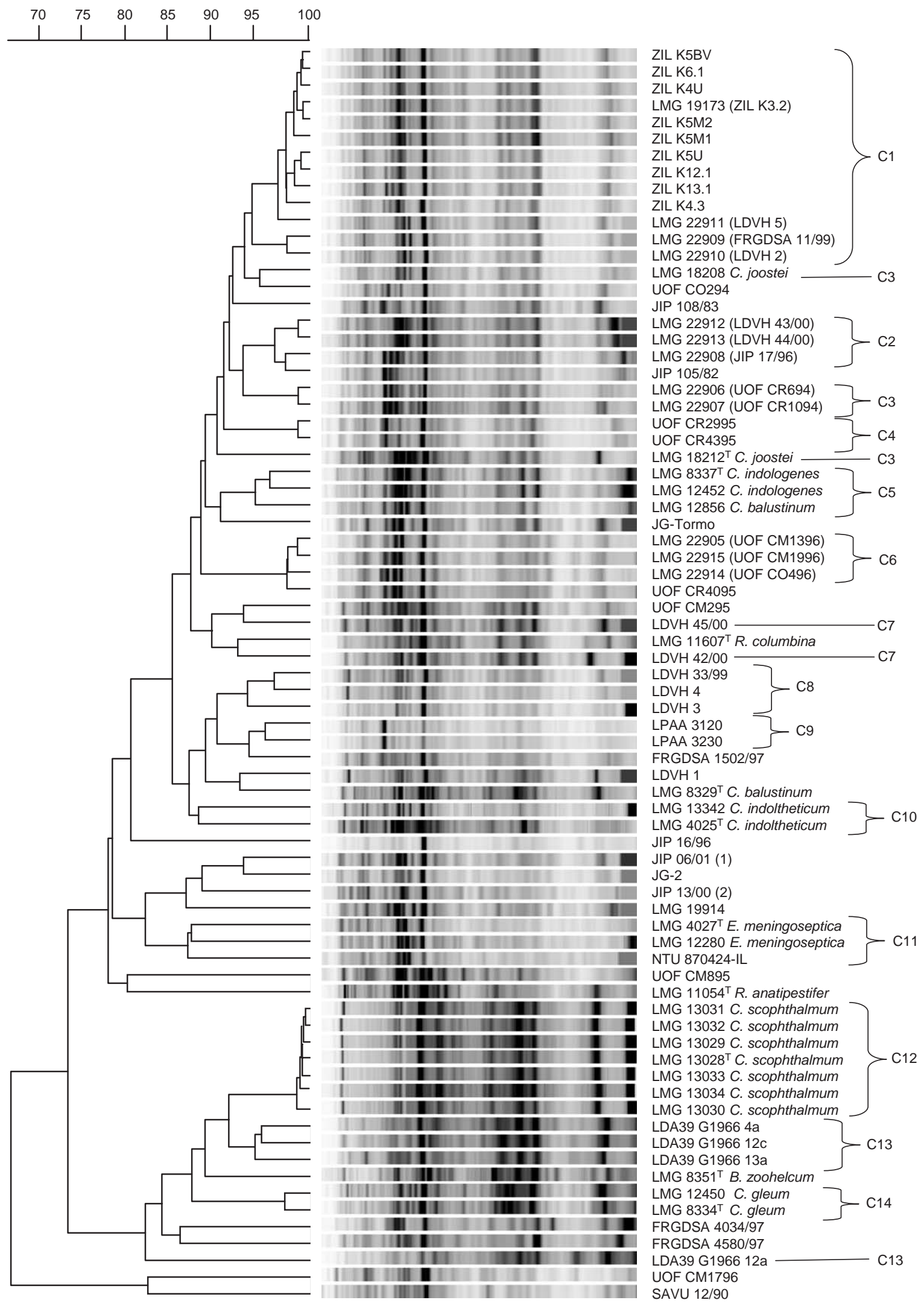

Fig. 2. Comparison of whole-cell protein profiles of the 75 strains studied and deduced dendrogram obtained by the UPGMA. The scale bar indicates the correlation values (Pearson's coefficient, $\times 100)$. The clusters $(\mathrm{C} 1-\mathrm{C} 14)$ that emerged from the analysis are indicated. 


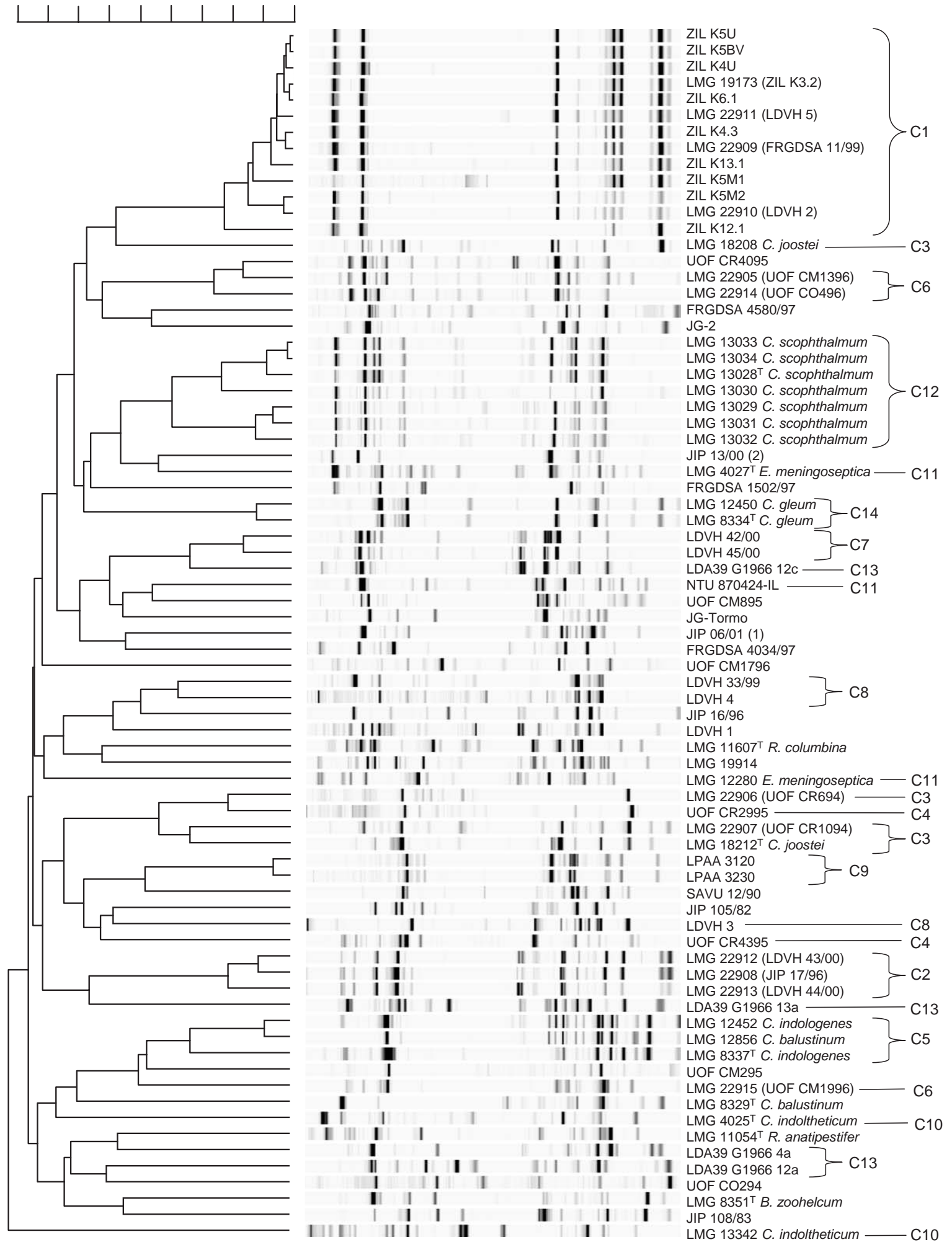

Fig. 3. Comparison of the RAPD profiles of the 75 strains studied and deduced dendrogram obtained by the UPGMA. The scale bar indicates the correlation values (Pearson's coefficient, $\times 100)$. The position of members of the clusters $(\mathrm{C} 1-\mathrm{C} 14)$ that emerged from SDS-PAGE analysis (Fig. 2) is indicated. 
other members of the family Flavobacteriaceae [5], although slight quantitative differences occurred and some strains contained additional minor components. In contrast, the reference strains of the Elizabethkingia, Riemerella, Kaistella and Sejongia species and of the recently described species $C$. defluvii, $C$. formosense and $C$. daecheongense displayed rather distinct fatty acid profiles. The fatty acid composition of the Riemerella strains had previously been determined using the same growth conditions than those used in this study [34,40] whereas somewhat different growth media and temperatures were used for the other organisms $[21-25,45,46]$. The major components included 15:0 iso, 17:0 iso $3-\mathrm{OH}, 17: 1 \omega 9 c$ iso and summed feature 4 (that comprises 15:0 iso $2-\mathrm{OH}, 16: 1 \omega 7 c, 16: 1 \omega 7 t$ or any combination of these fatty acids). A dendrogram based on the percentages of the major peaks of the FAMEs patterns was generated using Euclidian distance as similarity coefficient and UPGMA as clustering algorithm (data not shown). Four major groups of strains were delineated. Two small groups only comprised the members of SDS-PAGE clusters 4 and 11 (i.e., the two E. meningoseptica reference strains and the frog isolate NTU 870424-IL), respectively. A larger group included the members of clusters 6 and 9 , the B. zoohelcum type strain and several unclustered isolates. The fourth and largest group comprised the members of SDS-PAGE clusters $1,2,3,5,7,8,10,12,13$ and 14 , the $C$. balustinum type strain and several unclustered isolates. The type strains of the two Riemerella species and the isolates UOF CM895, UOF CM1796 and FRGDSA 4034/97 were not grouped and occupied separate branches at the base of the dendrogram.

\section{S rRNA gene sequence analysis}

The 16S rRNA gene sequences determined in this study are listed in Table 1 . Since the sequences already deposited in the GenBank nucleotide database (www.ncbi.nlm.nih.gov) for the type strains of $C$. balustinum, C. indoltheticum, C. gleum, C. indologenes and $E$. meningoseptica were short and/or of poor quality, they were determined again in this study, together with the 16S rRNA gene sequences of a second strain of $C$. balustinum, $C$. indoltheticum, $C$. joostei and $E$. meningoseptica. Fig. 4 shows the phylogenetic tree resulting from the comparison of the 16S rRNA gene sequences of a selection of fish isolates, of the reference strains and of several other relevant strains (i.e., the type strains of "C. proteolyticum" [44], C. defluvii [21], E. miricola [25], "C. massiliae" [12], C. formosense [46], C. daecheongense [22], "Haloanella gallinarum" [Pham, unpublished], Kaistella koreensis [24], Sejongia antarctica and S. jeonii [45], as well as a Chryseobacterium sp. from the gut of cockroach [13]). Owing to their short size (less than $800 \mathrm{bp}$ ), the 16S rRNA gene sequences of the strains LDVH 33/99 (AY468470) and LDVH 4 (AY468473) were not included in the analysis. The overall level of sequence similarity between members of the genus Chryseobacterium was high, reaching up to $97 \%$ between the different species. Even higher levels of 16S rRNA gene sequence similarity (i.e., 97.2-97.9\%) were recently published for closely related Chryseobacterium species $[20-22,44,46]$. The sequence of the strain SAVU $12 / 90$ was the most divergent compared to those of all other strains, and the primers used in this study were not able to amplify the 16S rRNA gene of the strain UOF CM1796. The sequence of the strain FRGDSA 4034/97 was clustered with those of the two newly described Sejongia species [45] (bootstrap value higher than $80 \%$ ) while the sequence of the frog isolate NTU 870424-IL was clustered with those of the $E$. meningoseptica and E. miricola type strains. All other isolates which $16 \mathrm{~S}$ rRNA gene was sequenced clearly fell within the main branch grouping all other Chryseobacterium species, although only few of them (e.g., UOF CR1094) were highly related to reference strains (Fig. 4).

\section{Discussion}

\section{Clustering of reference strains}

High DNA homologies had been reported between the two reference strains of $C$. indologenes [38], $C$. scophthalmum [29], C. gleum [38] and C. joostei [19] included in this study. Although the two strains of the three former species differed by several phenotypic traits, they shared identical fatty acid, protein and RAPD profiles and were consequently grouped in clusters 5, 12 and 14, respectively (Figs. 1-3). Conversely, the protein profiles of the two $C$. joostei strains occupied separate positions in the corresponding dendrogram (Fig. 2) (as previously reported [19]), although visual observation of the profiles actually revealed only limited differences. The two $C$. joostei strains also differed in phenotypic [20 and this study] and RAPD profiles but they displayed similar fatty acid profiles [19 and this study] and a very high DNA homology [19]. The isolates UOF CR694 and CR1094 from Atlantic salmon in Finland were closely related to the $C$. joostei type strain in fatty acid, SDS-PAGE, RAPD and phenotypic analyses. The two $C$. joostei reference strains and UOF CR1094 also shared more than $99.5 \%$ of their 16S rRNA gene sequence (Fig. 4). Moreover, the G+C content of the two fish isolates was similar to that of the C. joostei reference strains (i.e. $37-38 \mathrm{~mol} \% \mathrm{G}+\mathrm{C}$; L. Gardan, personal communication) and preliminary DNA-DNA hybridization experiments using the S1 nuclease technique showed that the two fish isolates and 
Table 2. Fatty acid composition (\%) of the bacterial strains included in this study

\begin{tabular}{|c|c|c|c|c|c|c|c|c|c|c|c|c|c|}
\hline Cluster & $\begin{array}{l}\text { Name and strain } \\
\text { number }\end{array}$ & $13: 0$ iso & Unknown $13.566^{\mathrm{a}}$ & $15: 0$ iso & $\begin{array}{l}15: 0 \text { iso } 3- \\
\mathrm{OH}\end{array}$ & $\begin{array}{l}\text { 15:0 } \\
\text { anteiso }\end{array}$ & $16: 0$ & $\begin{array}{l}16: 03- \\
\mathrm{OH}\end{array}$ & Unknown $16.580^{\mathrm{a}}$ & $17: 0$ iso & $\begin{array}{l}17: 0 \text { iso } 3- \\
\mathrm{OH}\end{array}$ & $\begin{array}{l}17: 1 \text { iso } \\
\omega 9 \mathrm{c}\end{array}$ & $\mathrm{SF} 4^{\mathrm{b}}$ \\
\hline \multirow[t]{13}{*}{1} & ZIL K4U & $\operatorname{Tr}$ & $\operatorname{Tr}$ & 34.5 & 3.3 & $\operatorname{Tr}$ & 1.3 & 1.1 & 1.7 & 1.2 & 21.5 & 21.7 & 11.5 \\
\hline & ZIL K5U & $\operatorname{Tr}$ & $\operatorname{Tr}$ & 34.0 & 3.4 & $\operatorname{Tr}$ & 1.1 & 1.1 & 1.7 & 1.1 & 21.3 & 21.8 & 12.3 \\
\hline & ZIL K5M1 & $\operatorname{Tr}$ & $\operatorname{Tr}$ & 34.2 & 3.4 & & 1.2 & 1.0 & 1.7 & 1.4 & 20.9 & 22.2 & 12.0 \\
\hline & ZIL K5M2 & $\operatorname{Tr}$ & $\operatorname{Tr}$ & 35.0 & 3.4 & $\operatorname{Tr}$ & 1.2 & 1.0 & 1.7 & 1.4 & 20.5 & 22.1 & 11.5 \\
\hline & ZIL K5BV & $\operatorname{Tr}$ & 1.0 & 34.8 & 3.3 & & 1.2 & 1.0 & 1.8 & 1.3 & 20.7 & 22.3 & 11.4 \\
\hline & LMG 19173 (ZIL K3.2) & $\operatorname{Tr}$ & 1.0 & 34.7 & 3.3 & & 1.1 & 1.0 & 1.6 & 1.4 & 20.4 & 22.5 & 11.9 \\
\hline & ZIL K4.3 & $\operatorname{Tr}$ & 1.0 & 36.2 & 3.5 & & 1.2 & 1.1 & 1.9 & 1.4 & 21.2 & 20.7 & 10.7 \\
\hline & ZIL K6.1 & $\operatorname{Tr}$ & 1.0 & 34.9 & 3.2 & $\operatorname{Tr}$ & 1.3 & 1.0 & 1.8 & 1.4 & 19.7 & 22.9 & 11.0 \\
\hline & ZIL K12.1 & $\operatorname{Tr}$ & 1.0 & 35.1 & 3.4 & & 1.3 & 1.1 & 1.8 & 1.4 & 21.2 & 21.5 & 11.1 \\
\hline & ZIL K13.1 & $\operatorname{Tr}$ & 1.0 & 34.8 & 3.3 & & 1.4 & 1.0 & 1.7 & 1.6 & 21.0 & 22.3 & 10.9 \\
\hline & $\begin{array}{l}\text { LMG } 22909 \text { (FRGDSA } \\
11 / 99)\end{array}$ & $\operatorname{Tr}$ & $\operatorname{Tr}$ & 37.5 & 3.0 & $\operatorname{Tr}$ & 1.3 & 1.1 & 1.5 & 1.8 & 20.1 & 21.5 & 9.7 \\
\hline & LMG 22910 (LDVH 2) & $\operatorname{Tr}$ & & 35.5 & 3.0 & $\operatorname{Tr}$ & 1.2 & 1.2 & 1.6 & 1.3 & 20.7 & 22.6 & 10.9 \\
\hline & LMG 22911 (LDVH 5) & $\operatorname{Tr}$ & & 36.5 & 3.0 & $\mathrm{Tr}$ & 1.4 & 1.2 & 1.7 & 1.5 & 20.6 & 21.9 & 10.1 \\
\hline \multirow[t]{3}{*}{2} & LMG 22908 (JIP 17/96) & $\operatorname{Tr}$ & 1.3 & 31.1 & 3.3 & & 1.3 & 1.1 & 1.8 & 1.5 & 22.5 & 20.5 & 14.6 \\
\hline & $\begin{array}{l}\text { LMG } 22912(\text { LDVH } \\
43 / 00)\end{array}$ & $\operatorname{Tr}$ & $\operatorname{Tr}$ & 30.5 & 3.4 & & 1.4 & 1.4 & 1.5 & 1.5 & 25.3 & 18.1 & 15.4 \\
\hline & $\begin{array}{l}\text { LMG } 22913 \text { (LDVH } \\
44 / 00)\end{array}$ & $\operatorname{Tr}$ & $\operatorname{Tr}$ & 30.5 & 3.6 & & 1.8 & 1.4 & 1.4 & 1.5 & 25.0 & 18.0 & 14.8 \\
\hline \multirow[t]{4}{*}{3} & C. joostei $\mathrm{LMG} 18212^{\mathrm{T}}$ & $\operatorname{Tr}$ & 1.1 & 34.5 & 2.4 & $\operatorname{Tr}$ & 1.0 & 1.0 & 1.6 & 1.1 & 18.4 & 25.8 & 11.4 \\
\hline & C. joostei LMG 18208 & 1.0 & 1.2 & 37.9 & 2.5 & & $\operatorname{Tr}$ & 1.2 & 1.3 & $\operatorname{Tr}$ & 19.4 & 21.9 & 11.2 \\
\hline & $\begin{array}{l}\text { LMG } 22906 \text { (UOF } \\
\text { CR694) }\end{array}$ & $\operatorname{Tr}$ & 1.1 & 34.3 & 2.8 & $\operatorname{Tr}$ & 1.4 & 1.0 & 1.7 & 1.1 & 20.1 & 22.9 & 11.5 \\
\hline & $\begin{array}{l}\text { LMG } 22907 \text { (UOF } \\
\text { CR1094) }\end{array}$ & $\operatorname{Tr}$ & 1.0 & 35.2 & 2.8 & $\operatorname{Tr}$ & 1.0 & 1.0 & 1.8 & 1.1 & 19.3 & 23.9 & 11.1 \\
\hline \multirow[t]{2}{*}{4} & UOF CR2995 & 6.0 & $\operatorname{Tr}$ & 45.8 & 3.1 & 7.4 & 1.3 & 2.1 & 1.5 & $\operatorname{Tr}$ & 14.8 & 3.2 & 11.0 \\
\hline & UOF CR4395 & 5.5 & 1.2 & 45.3 & 3.1 & 6.8 & 1.5 & 1.8 & 1.7 & $\operatorname{Tr}$ & 15.0 & 3.6 & 11.4 \\
\hline \multirow[t]{3}{*}{5} & $\begin{array}{l}\text { C. indologenes } \mathrm{LMG} \\
8337^{\mathrm{T}}\end{array}$ & $\operatorname{Tr}$ & 1.2 & 29.5 & 2.8 & & 1.0 & & 1.7 & $\operatorname{Tr}$ & 20.4 & 28.4 & 13.1 \\
\hline & $\begin{array}{l}\text { C. indologenes LMG } \\
12452\end{array}$ & $\operatorname{Tr}$ & 1.7 & 30.2 & 2.7 & & 1.0 & 1.1 & 1.6 & $\operatorname{Tr}$ & 18.9 & 27.0 & 12.5 \\
\hline & $\begin{array}{l}\text { C. balustinum LMG } \\
12856\end{array}$ & $\operatorname{Tr}$ & 1.7 & 32.3 & 2.5 & $\operatorname{Tr}$ & 1.0 & 1.1 & 1.6 & $\operatorname{Tr}$ & 18.5 & 27.0 & 10.8 \\
\hline \multirow[t]{3}{*}{6} & $\begin{array}{l}\text { LMG } 22914 \text { (UOF } \\
\text { CO496) }\end{array}$ & 1.7 & 1.3 & 43.0 & 2.9 & $\operatorname{Tr}$ & 1.0 & 1.1 & 1.7 & $\operatorname{Tr}$ & 20.0 & 14.9 & 9.2 \\
\hline & $\begin{array}{l}\text { LMG 22905 (UOF } \\
\text { CM1396) }\end{array}$ & 1.0 & 1.3 & 39.0 & 3.0 & $\operatorname{Tr}$ & 1.0 & 1.1 & 1.7 & $\operatorname{Tr}$ & 19.6 & 18.2 & 11.6 \\
\hline & $\begin{array}{l}\text { LMG 22915 (UOF } \\
\text { CM1996) }\end{array}$ & 1.1 & 1.2 & 39.4 & 3.0 & $\operatorname{Tr}$ & 1.0 & 1.0 & 1.8 & $\operatorname{Tr}$ & 19.4 & 18.1 & 11.9 \\
\hline
\end{tabular}




\begin{tabular}{|c|c|c|c|c|c|c|c|c|c|c|c|c|c|}
\hline Cluster & $\begin{array}{l}\text { Name and strain } \\
\text { number }\end{array}$ & $13: 0$ iso & Unknown $13.566^{\mathrm{a}}$ & $15: 0$ iso & $\begin{array}{l}15: 0 \text { iso } 3- \\
\mathrm{OH}\end{array}$ & $\begin{array}{l}15: 0 \\
\text { anteiso }\end{array}$ & $16: 0$ & $\begin{array}{l}16: 03- \\
\mathrm{OH}\end{array}$ & Unknown $16.580^{\mathrm{a}}$ & $17: 0$ iso & $\begin{array}{l}17: 0 \text { iso } 3- \\
\mathrm{OH}\end{array}$ & $\begin{array}{l}17: 1 \text { iso } \\
\omega 9 \mathrm{c}\end{array}$ & $\mathrm{SF} 4^{\mathrm{b}}$ \\
\hline \multirow[t]{2}{*}{7} & LDVH $42 / 00$ & $\operatorname{Tr}$ & & 33.3 & 2.6 & $\operatorname{Tr}$ & 1.6 & 1.0 & 1.6 & 1.6 & 21.2 & 23.4 & 12.0 \\
\hline & LDVH 45/00 & $\operatorname{Tr}$ & 1.0 & 30.5 & 2.4 & $\operatorname{Tr}$ & 1.4 & 1.1 & 1.5 & 1.2 & 20.2 & 25.9 & 13.0 \\
\hline \multirow[t]{3}{*}{8} & LDVH 33/99 & 1.0 & & 36.5 & 3.2 & $\operatorname{Tr}$ & 1.3 & 1.0 & 1.6 & $\operatorname{Tr}$ & 15.8 & 22.8 & 12.3 \\
\hline & LDVH 3 & $\operatorname{Tr}$ & & 29.6 & 2.6 & 1.0 & 1.2 & 1.8 & 1.4 & 1.5 & 16.3 & 24.1 & 15.5 \\
\hline & LDVH 4 & 1.4 & & 40.2 & 3.0 & 1.0 & 1.5 & 1.4 & 1.6 & 1.3 & 16.8 & 20.8 & 9.9 \\
\hline \multirow[t]{2}{*}{9} & LPAA 3120 & 1.8 & 1.0 & 44.0 & 3.0 & 3.0 & $\operatorname{Tr}$ & 1.1 & 1.6 & & 13.4 & 15.9 & 10.8 \\
\hline & LPAA 3230 & 2.1 & 1.0 & 44.7 & 2.9 & 3.1 & $\operatorname{Tr}$ & 1.3 & 1.6 & & 13.3 & 15.9 & 10.7 \\
\hline \multirow[t]{2}{*}{10} & $\begin{array}{l}\text { C. indoltheticum } \mathrm{LMG} \\
4025^{\mathrm{T}}\end{array}$ & $\operatorname{Tr}$ & 1.6 & 32.4 & 2.2 & 5.4 & 1.0 & 1.2 & 1.5 & $\operatorname{Tr}$ & 15.3 & 24.1 & 10.8 \\
\hline & $\begin{array}{l}\text { C. indoltheticum LMG } \\
13342\end{array}$ & $\operatorname{Tr}$ & 1.7 & 35.2 & 2.5 & 5.1 & 1.0 & 1.3 & 1.1 & 1.0 & 15.1 & 19.8 & 10.9 \\
\hline \multirow[t]{3}{*}{11} & $\begin{array}{l}\text { E. meningoseptica } \\
\text { LMG } 12279^{\mathrm{T}}\end{array}$ & 1.4 & 1.5 & 41.4 & 3.5 & 2.3 & $\operatorname{Tr}$ & 2.2 & 1.7 & $\operatorname{Tr}$ & 16.3 & 7.0 & 18.1 \\
\hline & $\begin{array}{l}\text { E. meningoseptica } \\
\text { LMG } 12280\end{array}$ & $\operatorname{Tr}$ & 2.0 & 36.8 & 3.0 & 2.2 & $\operatorname{Tr}$ & 2.2 & 1.7 & $\operatorname{Tr}$ & 16.6 & 8.1 & 22.0 \\
\hline & NTU 870424-IL & 1.0 & $\operatorname{Tr}$ & 44.0 & 3.0 & 1.5 & $\operatorname{Tr}$ & 1.8 & 1.6 & $\operatorname{Tr}$ & 17.6 & 8.7 & 17.0 \\
\hline \multirow[t]{2}{*}{12} & $\begin{array}{l}\text { C. scophthalmum } \mathrm{LMG} \\
13028^{\mathrm{T}}\end{array}$ & $\operatorname{Tr}$ & 3.1 & 36.0 & 2.8 & $\operatorname{Tr}$ & 1.0 & 1.2 & 1.3 & 1.0 & 17.1 & 21.8 & 11.1 \\
\hline & $\begin{array}{l}\text { C. scophthalmum LMG } \\
13032\end{array}$ & $\operatorname{Tr}$ & 3.5 & 34.8 & 3.0 & $\operatorname{Tr}$ & 1.1 & 1.4 & 1.8 & 1.1 & 17.2 & 21.1 & 12.0 \\
\hline \multirow[t]{4}{*}{13} & LDA39 G1966 4a & $\operatorname{Tr}$ & 2.9 & 30.3 & 2.5 & & 1.6 & 1.2 & 1.8 & 1.4 & 19.6 & 25.4 & 11.8 \\
\hline & LDA39 G1966 12a & $\operatorname{Tr}$ & 2.1 & 33.9 & 2.7 & & 1.9 & 1.3 & 1.9 & 1.2 & 20.7 & 21.1 & 12.2 \\
\hline & LDA39 G1966 12c & & 2.5 & 30.5 & 2.8 & & 1.2 & 1.1 & 1.8 & 1.1 & 20.9 & 24.7 & 12.7 \\
\hline & LDA39 G1966 13a & $\operatorname{Tr}$ & 2.4 & 35.6 & 2.6 & & 1.4 & 1.4 & 1.8 & 1.0 & 18.8 & 21.8 & 11.3 \\
\hline \multirow[t]{11}{*}{14} & C. gleum $\mathrm{LMG} 8334^{\mathrm{T}}$ & $\operatorname{Tr}$ & 1.6 & 31.6 & 2.6 & $\operatorname{Tr}$ & 1.0 & 1.1 & 1.9 & 1.0 & 19.1 & 25.0 & 12.9 \\
\hline & C. gleum $\mathrm{LMG} 12450$ & $\operatorname{Tr}$ & 1.9 & 29.8 & 2.3 & $\operatorname{Tr}$ & 1.3 & 1.2 & 1.6 & 1.3 & 19.2 & 26.5 & 12.7 \\
\hline & $\begin{array}{l}\text { C. balustinum } \mathrm{LMG} \\
8329^{\mathrm{T}}\end{array}$ & $\operatorname{Tr}$ & 1.6 & 32.4 & 2.7 & $\operatorname{Tr}$ & 1.6 & 1.4 & 1.3 & 1.0 & 16.9 & 27.2 & 9.2 \\
\hline & C. daecheongense & 1.6 & 1.5 & 51.2 & 2.0 & 1.0 & 1.8 & $\operatorname{Tr}$ & 1.0 & 3.0 & 15.7 & 7.6 & 10.3 \\
\hline & C. defluvii & 2.8 & $\operatorname{Tr}$ & 58.5 & 2.6 & 3.2 & 1.3 & $\operatorname{Tr}$ & $\operatorname{Tr}$ & 2.0 & 14.1 & 4.8 & 8.4 \\
\hline & C. formosense & 3.6 & $\operatorname{Tr}$ & 52.2 & 1.8 & 2.1 & 1.5 & $\operatorname{Tr}$ & 1.0 & 2.3 & 10.9 & 4.3 & 6.5 \\
\hline & E. miricola & 2.0 & 1.5 & 46.4 & 3.0 & 1.0 & 1.2 & 3.0 & 1.3 & $\operatorname{Tr}$ & 15.3 & 6.6 & 17.0 \\
\hline & $\begin{array}{l}\text { R. columbina } \mathrm{LMG} \\
11607^{\mathrm{T}}\end{array}$ & 12.1 & 0.5 & 48.1 & 3.3 & 20.6 & $\operatorname{Tr}$ & $\operatorname{Tr}$ & $\operatorname{Tr}$ & & 6.5 & & 1.8 \\
\hline & $\begin{array}{l}\text { R. anatipestifer } \mathrm{LMG} \\
11054^{\mathrm{T}}\end{array}$ & 9.3 & 1.0 & 60.6 & 5.2 & 5.9 & $\operatorname{Tr}$ & & 1.5 & & 11.7 & & \\
\hline & $\begin{array}{l}\text { B. zoohelcum LMG } \\
8351^{\mathrm{T}}\end{array}$ & 1.5 & 1.8 & 47.8 & 4.0 & & $\operatorname{Tr}$ & & 1.4 & & 13.5 & 17.5 & 9.0 \\
\hline & K. koreensis & 10.0 & & 52.0 & 3.0 & 11.0 & & & & & 9.0 & 8.0 & 2.0 \\
\hline
\end{tabular}




\begin{tabular}{|c|c|c|c|c|c|c|c|c|c|c|c|c|}
\hline S. antarctica & 2.5 & $\operatorname{Tr}$ & 13.6 & 1.0 & 15.2 & & & $\operatorname{Tr}$ & & 5.6 & 21.3 & 2.7 \\
\hline S. jeonii & 2.9 & $\operatorname{Tr}$ & 12.2 & 1.3 & 24.2 & & & $\operatorname{Tr}$ & & 4.4 & 8.6 & 2.6 \\
\hline JIP $105 / 82$ & $\mathrm{Tr}$ & 1.6 & 32.6 & 2.8 & $\operatorname{Tr}$ & 1.3 & 1.0 & 2.2 & 1.3 & 21.6 & 21.2 & 12.4 \\
\hline UOF CO294 & $\operatorname{Tr}$ & $\operatorname{Tr}$ & 32.6 & 3.1 & 2.2 & 1.6 & 1.0 & 1.5 & 1.3 & 20.3 & 19.9 & 11.5 \\
\hline UOF CM295 & $\operatorname{Tr}$ & 1.6 & 39.0 & 2.8 & 1.9 & 1.2 & 1.2 & 1.5 & $\operatorname{Tr}$ & 17.7 & 18.2 & 11.7 \\
\hline UOF CM895 & $\operatorname{Tr}$ & & 26.2 & 8.7 & 4.5 & 3.0 & 3.7 & $\operatorname{Tr}$ & $\operatorname{Tr}$ & 16.2 & 5.0 & 20.5 \\
\hline UOF CR4095 & 1.0 & 1.7 & 36.7 & 3.3 & $\operatorname{Tr}$ & 1.0 & 1.3 & 1.7 & $\operatorname{Tr}$ & 22.1 & 14.6 & 14.3 \\
\hline UOF CM1796 & $\operatorname{Tr}$ & $\operatorname{Tr}$ & 54.0 & 6.6 & 1.0 & $\operatorname{Tr}$ & $\operatorname{Tr}$ & 1.9 & $\operatorname{Tr}$ & 12.6 & 17.2 & 2.7 \\
\hline JIP 108/83 & 1.0 & 1.7 & 40.5 & 3.1 & $\operatorname{Tr}$ & 1.2 & $\operatorname{Tr}$ & 2.0 & 1.6 & 20.6 & 14.6 & 11.4 \\
\hline SAVU $12 / 90$ & $\operatorname{Tr}$ & 0.8 & 38.1 & 5.5 & 2.3 & $\operatorname{Tr}$ & & 1.5 & & 21.6 & 12.3 & 12.2 \\
\hline FRGDSA $1502 / 97$ & $\operatorname{Tr}$ & 1.7 & 33.7 & 3.2 & $\operatorname{Tr}$ & 2.2 & 1.2 & 1.8 & 2.3 & 17.6 & 23.8 & 10.1 \\
\hline FRGDSA 4034/97 & 15.2 & $\operatorname{Tr}$ & 32.6 & 2.4 & 19.4 & & & $\operatorname{Tr}$ & & 6.9 & 6.5 & 2.1 \\
\hline FRGDSA 4580/97 & 4.5 & 1.8 & 50.7 & 2.5 & 5.6 & 2.4 & 3.2 & 1.2 & & 11.9 & 4.4 & 8.8 \\
\hline JG-Torno & $\operatorname{Tr}$ & & 33.0 & 3.0 & & 1.3 & 1.0 & 1.6 & 1.6 & 22.5 & 25.5 & 9.3 \\
\hline $\mathrm{JG}-2$ & 1.3 & & 41.4 & 2.7 & 1.3 & 1.0 & 1.0 & 1.6 & $\operatorname{Tr}$ & 19.1 & 16.7 & 11.0 \\
\hline LDVH 1 & 1.3 & $\operatorname{Tr}$ & 41.2 & 3.2 & 1.0 & 1.2 & 1.2 & 1.5 & 1.1 & 17.1 & 19.1 & 9.7 \\
\hline JIP 13/00(2) & 1.5 & & 44.7 & 2.4 & $\operatorname{Tr}$ & 1.5 & 1.2 & 1.5 & 1.2 & 23.7 & 10.2 & 10.9 \\
\hline JIP 06/01(1) & 1.1 & & 39.9 & 3.2 & $\operatorname{Tr}$ & 1.3 & 1.2 & 1.6 & 1.0 & 21.8 & 16.0 & 11.2 \\
\hline LMG 19914 & $\operatorname{Tr}$ & & 33.4 & 2.7 & $\operatorname{Tr}$ & 1.3 & 1.4 & 1.5 & 1.1 & 20.6 & 22.7 & 13.9 \\
\hline
\end{tabular}

The fatty acid compositions of the type strains of several related organisms (i.e., C. defluvii [21], C. formosense [46], C. daecheongense [22], E. miricola [23,25], Kaistella koreensis [24], Sejongia antarctica and $S$. jeonii [45]) were included for comparison; some of these studies used different growth media and temperature. The fatty acid composition of "C. proteolyticum" [44] has not been determined. The strains that were grouped in 14 clusters by SDS-PAGE analysis are listed first.

Fatty acid percentages amounting to less than $1 \%$ of the total fatty acids in all strains were not included; therefore, the percentages do not total $100 \%$. Tr, trace (less than $1 \%$ ); blank, not detected. Only major components were included in the table. Other, minor fatty acids also occurred in the following strains: all members of cluster 4 contained $1.0 \%$ of $16: 0$ iso $3-\mathrm{OH}$; $C$ indologenes LMG 12452 contained $1.0 \%$ each of $18: 1 \omega 5 c$ and SF5; "C. balustinum" LMG 12856 contained 1.0\% of SF5; the strain LDVH 3 contained 1.0\% each of 16:0 iso 3-OH and 17:0 2-OH; the strain LPAA 3230 contained $1.0 \%$ of $18: 1 \omega 5 c$; C. indoltheticum LMG $4025^{\mathrm{T}}$ contained $1.0 \%$ each of $16: 0$ iso $3-\mathrm{OH}$ and 18:1 $\omega 5 c$; C. indoltheticum LMG 13342 contained $2.7 \%$ of $17: 02-\mathrm{OH}$ and $1.0 \%$ of $18: 1 \omega 5 c$; E. meningoseptica LMG 12280 and the strain NTU 870424-IL each contained 1.0\% of 16:1 $\omega 5$ c; C. formosense contained 1.0\% of $16: 0$ iso 3-OH; R. columbina LMG $11607^{\mathrm{T}}$ contained $1.9 \%$ of $13: 0$ anteiso, $1.2 \%$ of $14: 0$ iso and $1.0 \%$ each of $16: 0$ iso $3-\mathrm{OH}$ and 17:0 2-OH; $R$. anatipestifer LMG $11054^{\mathrm{T}}$ contained $1.3 \%$ of $14: 0$ iso and $1.6 \%$ of $16: 0$ iso $3-\mathrm{OH}$; B. zoohelcum $\mathrm{LMG} 8351^{\mathrm{T}}$ contained $1.5 \%$ each of $18: 1 \omega 5 c$ and SF5; $K$. koreensis contained 2.0\% each of 14:0 iso and 16:0 iso 3-OH; S. antarctica contained 3.2\% of 13:0 anteiso, 1.5\% of $14: 0$ iso, $2.6 \%$ of $15: 0,1.9 \%$ of $15: 02-\mathrm{OH}$ $6.6 \%$ of $15: 1$ anteiso A, $2.8 \%$ of $16: 0$ iso, $5.1 \%$ of $16: 0$ iso $3-\mathrm{OH}, 3.6 \%$ of $16: 1$ iso $\mathrm{H}, 3.3 \%$ of $17: 02-\mathrm{OH}, 2.5 \%$ of $17: 1$ anteiso $\omega 9 \mathrm{c}$ and $1.5 \%$ of $18: 1 \omega 5 c ; \mathrm{S}$. jeonii contained $1.0 \%$ of 12.0 iso, $3.6 \%$ of $13: 0$ anteiso, $5.0 \%$ of $14: 0$ iso, $1.5 \%$ of $15: 0,1.9 \%$ of $15: 02-\mathrm{OH}, 5.7 \%$ of $16: 0$ iso, $9.0 \%$ of $16: 0$ iso $3-\mathrm{OH}, 9.1 \%$ of $16: 1$ iso $\mathrm{H}, 2.3 \%$ of $17: 02-\mathrm{OH}$ and $1.9 \%$ of $17: 1$ anteiso $\omega 9 c$; the strain $\mathrm{UOF}$ CO294 contained $1.5 \%$ of 17:0 2-OH; the strain UOF CM295 contained 1.1\% of 17:0 2-OH; the strain UOF CM895 contained 3.2\% of 15:0, 1.5\% of 15:1 anteiso A and 1.7\% of $17: 02-\mathrm{OH}$; the strain UOF CM1796 contained 1.0\% of 15:0; the strain SAVU 12/90 contained 1.8\% of $15: 1$ anteiso A; the strain JIP 16/96 contained 1.0\% of 18:1 $\omega 5 c$ and $1.4 \%$ of SF5; the strain FRGDSA 4034/ 97 contained $5.9 \%$ of $13: 0$ anteiso, $1.5 \%$ of $15: 02-\mathrm{OH}, 1.1 \%$ of $16: 1 \omega 5 c, 1.3 \%$ of $17: 02-\mathrm{OH}, 1.7 \%$ of $18: 1 \omega 5 c$ and $1.1 \%$ of SF5; and the strain FRGDSA $4580 / 97$ contained $1.1 \%$ of $14: 0$ and $1.0 \%$ of 17:0 2-OH.

${ }^{\mathrm{a}}$ Unknown fatty acid; numbers indicate equivalent chain length.

${ }^{b}$ Fatty acids that could not be separated by gas chromatography using the Microbial Identification System (Microbial ID) software were considered summed features. Summed feature 4 contains

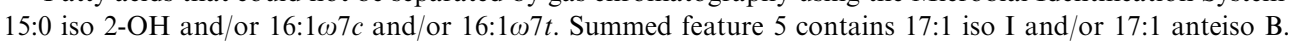




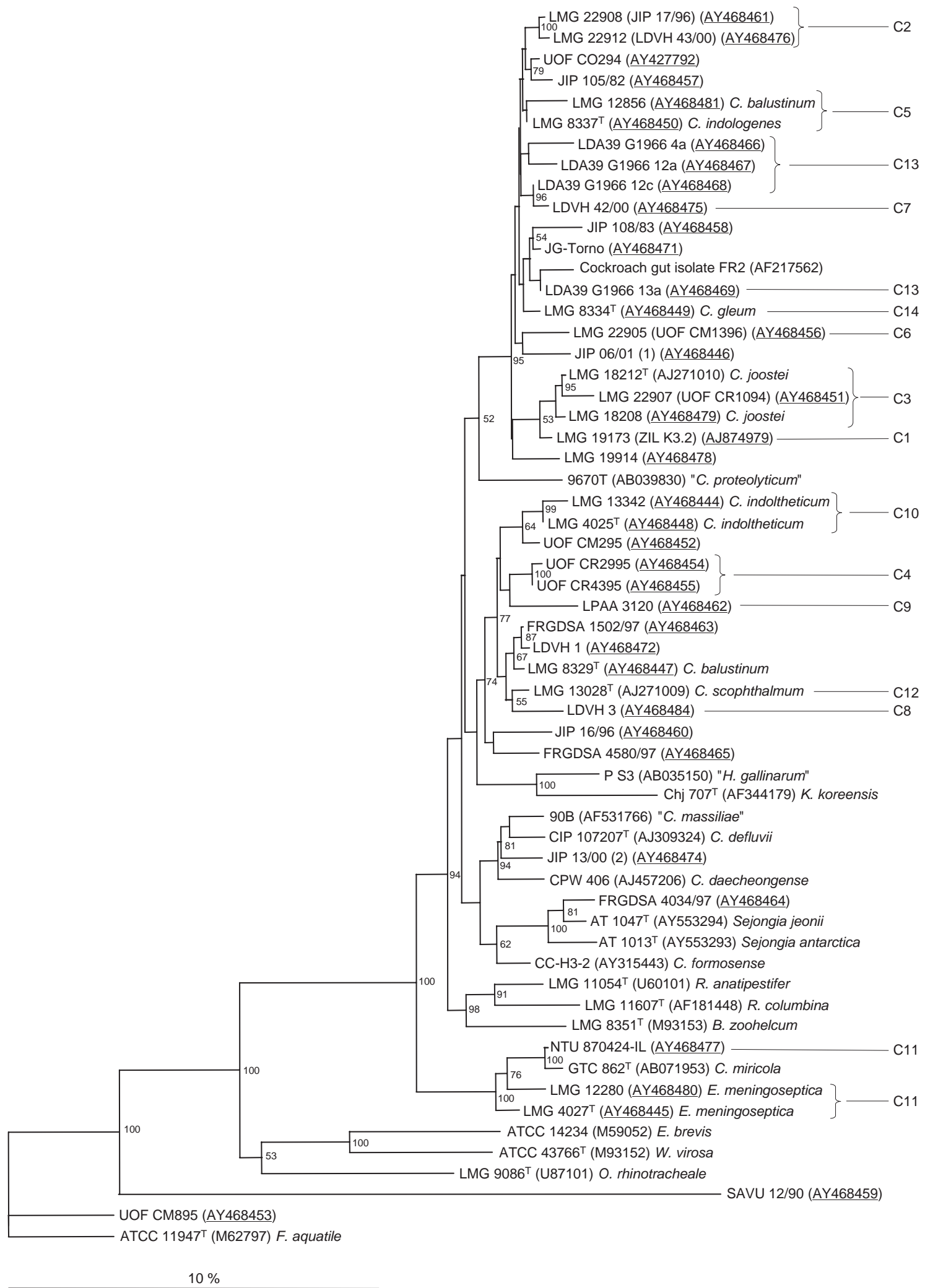

Fig. 4. Distance tree showing the phylogenetic relationships of a selection of fish isolates and other related members of the Chryseobacterium-Elizabethkingia-Bergeyella-Riemerella branch. The tree was constructed using the 16S rRNA gene sequences, the model of Jukes and Cantor and the neighbor-joining method included in the PAUP software [36]. Flavobacterium aquatile and the fish isolate UOF CM895 were used as outgroups. Bootstrap values (percentages of 1000 replicates) of $>50 \%$ are shown. GenBank accession numbers are shown in parentheses. The underlined numbers correspond to those $16 \mathrm{~S}$ rRNA gene sequences that have been determined in this study; the other sequences were retrieved from GenBank. Bar, 10\% sequence divergence. The position of members of the clusters (C1-C14) that emerged from SDS-PAGE analysis (Fig. 2) is indicated. 
the $C$. joostei type strain shared $73-80 \%$ DNA relatedness with a $\Delta T_{m}$ (thermal stability of heteroduplexes) value of $3.3{ }^{\circ} \mathrm{C}$ (data not shown). Hence, the isolates UOF CR694 and CR1094 represent strains of $C$. joostei and can be considered members of cluster 3 together with the $2 C$. joostei reference strains although all four strains were actually not grouped by any analysis (Figs. 1-3).

No DNA homology data were available for the couples of reference strains of $C$. balustinum, $C$. indoltheticum and Elizabethkingia meningoseptica included in this study. All techniques, including the sequencing of the 16S rRNA gene (Fig. 4), actually grouped the " $C$. balustinum" strain LMG 12856 with the reference strains of $C$. indologenes within cluster 5, while the type strain of $C$. balustinum remained isolated. These results demonstrated that the strain LMG 12856 had been wrongly attributed to $C$. balustinum and that it actually most likely belongs to $C$. indologenes. The two reference strains of $C$. indoltheticum and $E$. meningoseptica were grouped in clusters 10 and 11, respectively, when their protein and phenotypic profiles were compared, but they displayed different RAPD patterns (Figs. 1-3) and slightly different fatty acid patterns (Table 2). The frog isolate NTU 870424-IL was also included in cluster 11 following SDS-PAGE and phenotypic analyses; since its fatty acid profile and $16 \mathrm{~S}$ rRNA gene sequence were very similar to those of the $E$. meningoseptica type strain, this isolate most probably belongs to this species.

\section{Clustering of new isolates and delineation of potential new taxa}

Besides the clusters that comprised Chryseobacterium reference strains, our interest focussed on those clusters that included at least three fish isolates originating from at least two different origins, i.e. clusters 1,2 and 6 . The ten ZIL isolates in cluster 1, retrieved from the same koi carp farm in Belgium (and, for some of them, from the same fish), exhibited a very high level of homogeneity by all techniques used in this study (Figs. 1-3 and Table 2) and presumably represented different isolates of the same clone. Hence, the protein, fatty acid, RAPD and phenotypic analyses performed in this study were highly repeatable. The three other isolates in cluster 1 (i.e., LDVH 2, LDVH 5 and FRGDSA 11/99) had been isolated in France from skin ulcers or internal organs of recently imported koi carp and goldfish (Table 1). They displayed identical RAPD and fatty acid patterns but slightly different protein and phenotypic profiles compared to the 10 ZIL isolates (Figs. 1-3, Table 2).

Cluster 2 comprised three strains isolated in France from internal organs of three different tropical ornamental fish (Table 1). The two strains originating from the same facility (i.e., LDVH 43/00 and 44/00) shared identical protein and phenotypic profiles while the profiles of the strain JIP 17/96 were slightly different (Figs. 1 and 2). The three strains displayed identical fatty acid composition (Table 2) and RAPD profiles (Fig. 3), and the strains LDVH 43/00 and JIP 17/96 also shared a very high $16 \mathrm{~S}$ rRNA gene sequence similarity (Fig. 4). Although the protein profile of the strain JIP $105 / 82$ was very similar to those of members of cluster 2, its RAPD and phenotypic profiles were quite different.

Cluster 6 contained three isolates from external lesions or internal organs of Atlantic salmon and brown trout reared in Finland (Table 1). The three strains exhibited very similar protein, fatty acid and phenotypic patterns (Figs. 1, 2 and Table 2). Visual comparison showed that the apparently divergent RAPD profile of the strain UOF CM1996 was actually rather similar to the profile of the two other strains (Fig. 3). Although the strain UOF CR4095 displayed protein, fatty acid and RAPD profiles very similar to those of members of cluster 6 , it was not included in the cluster owing to significant phenotypic discrepancies (Fig. 1).

Interestingly, none of the fish isolates included in this study could be attributed to the two Chryseobacterium species previously reported from fish, i.e. C. balustinum and $C$. scophthalmum. However, two isolates from external lesions of Atlantic salmon reared in Finland were unexpectedly attributed to $C$. joostei, a bacterial species only reported from raw cow milk in South Africa to date. As a result of this study, 18 among the 35 isolates studied could be clustered or allocated to existing Chryseobacterium species while the other strains occupied separate or uncertain positions in the genus Chryseobacterium, a situation strikingly similar to that resulting from the polyphasic study of a large collection of dairy isolates in South Africa [19]. Hence, our study confirmed that the delineation of clusters of strains that could constitute new species is particularly difficult in the genus Chryseobacterium. However, clusters 1, 2 and 6, grouping 3-13 isolates originating from 2 or 3 different geographical areas or facilities, were distinctly delineated and probably constitute the core of three new Chryseobacterium species. Extensive DNA-DNA hybridization experiments and the identification of differential phenotypic traits will be necessary to confirm their specific status.

The three fish isolates UOF CM895, UOF CM1796, and SAVU 12/90 differed clearly from all other isolates and reference strains studied in most characteristics although their API 20E and 20NE profiles were similar to those of members of the genera Chryseobacterium and Elizabethkingia. Comparison of the 16S rRNA gene sequences of UOF CM895 and SAVU 12/90 with the GenBank nucleotide database using BLAST-n searches revealed that they still belong to the family 
Flavobacteriaceae and that their closest relatives are members of the genera Flavobacterium and Vitellibacter, respectively.

\section{Ecology and pathological significance of the isolates}

Although some members of the genus Chryseobacterium had already been reported from freshwater environments (Table 1), this study demonstrated that Chryseobacterium strains are widely distributed in fish farms and may be readily isolated from diseased fish. Except the frog isolate NTU 870424-IL, all strains included in this study were retrieved from fish and represented an interesting variety of geographical, zoological (i.e., various fish taxa), and environmental (i.e., wild, farmed, or ornamental freshwater fish species) sources. This study also demonstrated that Chryseobacterium strains belonging to different clusters may occur in the same fish farm. For instance, the five UOF strains originating from the same salmon farm in Finland (noted CR in the strain number [Table 1]) were divided between clusters 3 (i.e., C. joostei) and 4 or remained isolated. Conversely, strains belonging to the same cluster were retrieved from different fish farms or facilities; for instance, cluster 6 contained isolates from the Finish salmon farms CO and CM. Although all fish isolates originated from diseased individuals and about half of them were isolated from internal organs, their virulence for fish has not been demonstrated unequivocally. Preliminary experimental infection studies using one of the salmon isolates from Finland suggested that this strain was only moderately virulent for salmon (P. Rintamäki-Kinnunen, personal communication). The fact that a number of isolates had been retrieved from recently imported fish (Table 1) suggests that the bacteria they harboured actually were opportunistic pathogens which took advantage from the severe stress resulting from international transport. Since this study was completed, however, the authors isolated (or received from other laboratories) a significant number of additional Chryseobacterium sp. strains from diseased fish, demonstrating that Chryseobacterium strains potentially represent emergent pathogens in fish.

Most isolates included in this study exhibited high levels of resistance to many antimicrobial agents. This result, that is the subject of another paper [27], is consistent with published data dealing with human clinical Chryseobacterium and Elizabethkingia isolates [3]. Hence, the possible contamination of immunocompromised humans by resistant strains originating from fish or frogs farmed for ornamental, food or research purpose should not be underestimated. In this study, the bullfrog isolate NTU 870424-IL from Taiwan was clearly identified as E. meningoseptica. Since this study was completed, similar strains have repeatedly been isolated from the same frog species in Taiwan (S.-C. Chen, personal communication) and a bacterial strain retrieved from a farmed clawed frog (Xenopus laevis) in France was also identified as E. meningoseptica (strain CIP 108653; N. Keck and J.-F. Bernardet, unpublished data). These reports confirm published occurrences of this human pathogen in various frog species $[11,15,26]$. Moreover, the first isolations of $E$. meningoseptica from fish (i.e., koi carp [strain CIP 108654] and snake fish [Erpetoichthys calabaricus]) were reported recently (N. Keck, personal communication). Again, the clawed frog and the two fish had recently been imported in France, from a natural pond in South Africa and from facilities in China and Africa, respectively.

\section{Acknowledgements}

The authors thank all of the individuals who provided bacterial strains (Table 1). J.-F. B. is indebted to L. Gardan (then in Institut National de la Recherche Agronomique, Station de Pathologie Végétale, Angers, France) who determined the $\mathrm{G}+\mathrm{C}$ content of the strains UOF CR694 and CR1094, to P. Rintamäki-Kinnunen (Department of Biology, University of Oulu, Finland) who performed preliminary experimental infection studies, and to P. Dawyndt (Laboratorium voor Microbiologie, University of Ghent, Belgium) for his kind help in fatty acid analysis.

\section{References}

[1] R.L. Anacker, E.J. Ordal, Study of a bacteriophage infecting the myxobacterium Chondrococcus columnaris, J. Bacteriol. 70 (1955) 738-741.

[2] G.I. Barrow, R.K.A. Feltham, Cowan and Steel's Manual for the Identification of Medical Bacteria, third ed., Cambridge University Press, Cambridge, 1993.

[3] J.-F. Bernardet, C. Hugo, B. Bruun, The genus Chryseobacterium, In: M. Dworkin, et al. (Eds.), The Prokaryotes: An Evolving Electronic Resource for the Microbiological Community, third ed., release 3.20, 2005 Springer, New York, http://link.springer-ny.com/link/service/books/ 10125

[4] J.-F. Bernardet, Y. Nakagawa, B. Holmes, Proposed minimal standards for describing new taxa of the family Flavobacteriaceae and emended description of the family, Int. J. Syst. Evol. Microbiol. 52 (2002) 1049-1070.

[5] J.-F. Bernardet, P. Segers, M. Vancanneyt, F. Berthe, K. Kersters, P. Vandamme, Cutting a Gordian knot: emended classification and description of the genus Flavobacterium, emended description of the family Flavobacteriaceae, and proposal of Flavobacterium hydatis nom. nov. (basonym, Cytophaga aquatilis Strohl and Tait 1978), Int. J. Syst. Bacteriol. 46 (1996) 128-148. 
[6] J. Brisou, C. Tysset, B. Vacher, Etude de trois souches microbiennes de la famille des Pseudomonadaceae dont la synergie provoque une maladie de caractére septicémique chez les poissons blancs de la Dordogne du Lot et de leurs affluents, Ann. Inst. Pasteur 96 (1959) 689-696.

[7] J. Brosius, T.J. Dull, H.F. Noller, Complete nucleotide sequence of a 23S ribosomal RNA gene from Escherichia coli, Proc. Natl. Acad. Sci. USA 77 (1980) 201-204.

[8] J. Brosius, M.L. Palmer, P.J. Kennedy, H.F. Noller, Complete nucleotide sequence of a $16 \mathrm{~S}$ ribosomal RNA gene from Escherichia coli, Proc. Natl. Acad. Sci. USA 75 (1978) 4801-4805.

[9] V.I. Brown, E.J.L. Lowbury, Use of an improved cetrimide agar medium and other culture method for Pseudomonas aeruginosa, J. Clin. Pathol. 18 (1965) $752-756$

[10] L.L.Jun. Campbell, O.B. Williams, A study of chitindecomposing microorganisms of marine origin, J. Gen. Microbiol. 5 (1951) 894-905.

[11] H.-Y. Chung, On the bacterial disease of captive bullfrog, In: G.-H. Kou, H. Wakabayashi, I.-C. Liao, S.-N. Chen, C.-F. Lo (Eds.), Proceedings of the Republic of ChinaJapan Symposium on Fish Diseases, NSC Symposium Series No. 16, The National Science Council, Taiwan, 1990, pp. 81-89.

[12] M. Drancourt, P. Berger, D. Raoult, Systematic 16S rRNA gene sequencing of atypical clinical isolates identified 27 new bacterial species associated with humans, J. Clin. Microbiol. 42 (2004) 2197-2202.

[13] J.E. Dugas, L. Zurek, B.J. Paster, B.A. Keddie, E.R. Leadbetter, Isolation and characterization of a Chryseobacterium strain from the gut of the American cockroach, Periplaneta americana, Arch. Microbiol. 175 (2001) 259-262.

[14] C.J. González, J.A. Santos, M.-L. García-López, A. Otero, Psychrobacters and related bacteria in freshwater fish, J. Food Prot. 63 (2000) 315-321.

[15] S.L. Green, D.M. Bouley, R.J. Tolwani, K.S. Waggie, B.D. Lifland, G.M. Otto, J.E. Ferrell, Identification and management of an outbreak of Flavobacterium meningosepticum infection in a colony of South African clawed frogs (Xenopus laevis), J. Am. Vet. Med. Assoc. 214 (1999) 1833-1838.

[16] F.C. Harrison, The discolouration of halibut, Can. J. Res. 1 (1929) 214-239.

[17] T.C. Hsu, W.D. Waltman, E.B. Shotts, Correlation of extracellular enzymatic activity and biochemical characteristics with regard to virulence of Aeromonas hydrophila, Dev. Biol. Stand. 49 (1981) 101-111.

[18] C.J. Hugo, P.J. Jooste, Preliminary differentiation of food strains of Chryseobacterium and Empedobacter using multilocus enzyme electrophoresis, Food Microbiol. 14 (1997) 133-142.

[19] C.J. Hugo, P.J. Jooste, P. Segers, M. Vancanneyt, K. Kersters, A polyphasic taxonomic study of Chryseobacterium strains isolated from dairy sources, Sys. Appl. Microbiol. 22 (1999) 586-595.

[20] C.J. Hugo, P. Segers, B. Hoste, M. Vancanneyt, K. Kersters, Chryseobacterium joostei sp. nov., isolated from dairy environment, Int. J. Syst. Evol. Microbiol. 53 (2003) 771-777.

[21] P. Kämpfer, U. Dreyer, A. Neef, W. Dott, H.-J. Busse, Chryseobacterium defluvii sp. nov., isolated from wastewater, Int. J. Syst. Evol. Microbiol. 53 (2003) 93-97.

[22] K.K. Kim, H.-S. Bae, P. Schumann, S.-T. Lee, Chryseobacterium daecheongense sp. nov., isolated from freshwater lake sediment, Int. J. Syst. Evol. Microbiol. 55 (2005) 133-138.

[23] K.K. Kim, M.-K. Kim, J.H. Lim, H.Y. Park, S.-T. Lee, Transfer of Chryseobacterium meningosepticum and Chryseobacterium miricola to Elisabethkingia gen. nov. as Elisabethkingia meningoseptica comb. nov. and Elisabethkingia miricola comb. nov., Int. J. Syst. Evol. Microbiol. 55 (2005) 1287-1293.

[24] M.K. Kim, W.-T. Im, Y.K. Shin, J.H. Lim, S.-H. Kim, B.C. Lee, M.-Y. Park, K.Y. Lee, S.-T. Lee, Kaistella koreensis gen. nov., sp. nov., a novel member of the Chryseobacterium-Bergeyella-Riemerella branch, Int. J. Syst. Evol. Microbiol. 54 (2004) 2319-2324.

[25] Y. Li, Y. Kawamura, N. Fujiwara, T. Naka, H. Liu, X. Huang, K. Kobayashi, T. Ezaki, Chryseobacterium miricola sp. nov., a novel species isolated from condensation water of space station Mir, Syst. Appl. Microbiol. 26 (2003) 523-528.

[26] M.J. Mauel, D.L. Miller, K.S. Frazier, M.H. Hines II, Bacterial pathogens isolated from cultured bullfrogs (Rana catesbeiana), J. Vet. Diagn. Invest. 14 (2002) 431-433.

[27] C. Michel, O. Matte-Tailliez, B. Kerouault, J.-F. Bernardet, Resistance pattern and assessment of phenicol agents' minimum inhibitory concentration in multiple drug resistant Chryseobacterium isolates from fish and aquatic habitats, J. Appl. Microbiol., accepted for publication.

[28] M. Mudarris, B. Austin, Systemic disease in turbot Scophthalmus maximus caused by a previously unrecognised Cytophaga-like bacterium, Dis. Aquat. Org. 6 (1989) 161-166.

[29] M. Mudarris, B. Austin, P. Segers, M. Vancanneyt, B. Hoste, J.-F. Bernardet, Flavobacterium scophthalmum sp. nov., a pathogen of turbot (Scophthalmus maximus L.), Int. J. Syst. Bacteriol. 44 (1994) 447-453.

[30] B. Pot, P. Vandamme, K. Kersters, Analysis of electrophoretic whole-organism protein fingerprints, In: M. Goodfellow, A.G. O'Donnell (Eds.), Chemical Methods in Prokaryotic Systematics, Wiley, Chichester, UK, 1994, pp. 493-521.

[31] H. Reichenbach, Order I. Cytophagales Leadbetter 1974, In: J.T. Staley, M.P. Bryant, N. Pfennig, J.G. Holt (Eds.), Bergey's Manual of Systematic Bacteriology, vol. 3, Williams and Wilkins, Baltimore, 1989, pp. 2011-2013.

[32] C. Richard, M. Kiredjian, Laboratory methods for the identification of strictly aerobic Gram-negative bacilli, Institut Pasteur, Paris, 1995.

[33] N. Saitou, M. Nei, The neighbor-joining method: a new method for reconstructing phylogenetic trees, Mol. Biol. Evol. 4 (1987) 406-425.

[34] P. Segers, W. Mannheim, M. Vancanneyt, K. De Brandt, K.-H. Hinz, K. Kersters, P. Vandamme, Riemerella anatipestifer gen. nov., the causative agent of septicemia 
anserum exsudativa, and its phylogenetic affiliation within the Flavobacterium-Cytophaga rRNA homology group, Int. J. Syst. Bacteriol. 43 (1993) 768-776.

[35] R.M. Smibert, N.R. Krieg, Phenotypic characterization, In: P. Gerhardt, R.G.E. Murray, W.A. Wood, N.R. Krieg (Eds.), Methods for General and Molecular Bacteriology, American Society for Microbiology, Washington, DC, 1994, pp. 607-654.

[36] D.L. Swofford, PAUP* Phylogenetic Analysis Using Parsimony (* and Other Methods), Version 4.0b10, Sinauer Associates, Sunderland, MA, 2003.

[37] P. Tailliez, J. Tremblay, S.D. Ehrlich, A. Chopin, Molecular diversity and relationship within Lactococcus lactis, as revealed by randomly amplified polymorphic DNA (RAPD), Syst. Appl. Microbiol. 21 (1998) 530-538.

[38] J. Ursing, B. Bruun, Genetic heterogeneity of Flavobacterium group IIb and Flavobacterium breve demonstrated by DNA-DNA hybridization, Acta Pathol. Microbiol. Immunol. Scand. Sect. B 99 (1991) 780-786.

[39] M. Vancanneyt, P. Segers, L. Hauben, J. Hommez, L.A. Devriese, B. Hoste, P. Vandamme, K. Kersters, Flavobacterium meningosepticum, a pathogen in birds, Int. J. Syst. Evol. Microbiol. 32 (1994) 2398-2403.

[40] M. Vancanneyt, P. Vandamme, P. Segers, U. Torck, R. Coopman, K. Kersters, K.-H. Hinz, Riemerella columbina sp. nov., a bacterium associated with respiratory disease in pigeons, Int. J. Syst. Bacteriol. 49 (1999) 289-295.

[41] P. Vandamme, J.-F. Bernardet, P. Segers, K. Kersters, B. Holmes, New perspectives in the classification of the flavobacteria: description of Chryseobacterium gen. nov., Bergeyella gen. nov., and Empedobacter nom. rev, Int. J. Syst. Bacteriol. 44 (1994) 827-831.

[42] P. Vandamme, B. Pot, M. Gillis, P. De Vos, K. Kersters, J. Swings, Polyphasic taxonomy, a consensus approach to bacterial systematics, Microbiol. Rev. 60 (1996) 407-438.

[43] P.A. West, R.R. Colwell, Identification and classification of the Vibrionaceae - an overview, In: R.R. Colwell (Ed.), Vibrios in the Environment, Wiley, New York, 1984, pp. 285-363.

[44] S. Yamaguchi, M. Yokoe, A novel protein-deamidating enzyme from Chryseobacterium proteolyticum sp. nov., a newly isolated bacterium from soil, Appl. Environ. Microbiol. 66 (2000) 3337-3343.

[45] H. Yi, H.I. Yoon, J. Chun, Sejongia antarctica gen. nov., sp. nov., Sejongia jeonii sp. nov., isolated from the Antarctic, Int. J. Syst. Evol. Microbiol. 55 (2005) 409-416.

[46] C.C. Young, P. Kämpfer, F.T. Shen, W.A. Lai, A.B. Arun, Chryseobacterium formosense sp. nov., isolated from the rhizosphere of Lactuca sativa L. (Garden lettuce), Int. J. Syst. Evol. Microbiol. 55 (2005) 423-426. 